\title{
RESISTÊNCIA À CORROSÃO DE AMÁLGAMAS E DE LIGAS À BASE DE GÁLIO, SEM E COM ADESIVOS, ATRAVÉS DO MÉTODO DE PERDA DE PESO E ANÁLISE DA RUGOSIDADE DE SUPERFÍCIE
}

PAULO HUMAITÁ DE ABREU

Trabalho apresentado à Faculdade de Odontologia de Bauru, Universidade de São Paulo, como parte dos requisitos para Obtenção do grau de Doutor em Odontologia, área de Dentística - Opção Materiais Dentários.

BAURU 


\section{DEDICATÓRIA}

Aos meus filhos

Paulo Humaitá de Abreu Junior

e

Bianca Salvi de Abreu

Por serem a continuação da minha vida

E através de novos caminhos a trilhar,

O sucesso com certeza alcançar. 


\section{AGRADECIMENTOS}

"As montanhas e vales

Desertos e mares

Que atravesso

Me levam pra perto de Ti.

Minhas provações não são maiores

Do que o meu Deus

E não vão impedir de caminhar

Se diante de mim não se abrir o mar

Deus vai me fazer andar sobre as águas." 
Agradeço a DEUS,

pela Graça recebida.

Aos meus pais

Dr. Wilson de Abreu e D. Leonor

não faltando amor, carinho, compreensão e dedicação a mim;

Aos meus irmãos

Wilson Roberto, João e Wanderley

pelo incentivo e estímulo.

Para Kátia Cristina Salvi de Abreu e familiares

pelo apoio e carinho reconhecidos. 
Ao Prof. Dr. José Mondelli pela orientação deste trabalho, compreensão e incentivo. Registro minha admiração pelo seu exemplo de pessoa, dom de ensinar e pesquisador reconhecido mundialmente. 
Ao Prof. Dr. César Antunes de Freitas, co-orientador desta tese, pela honestidade como pesquisador e amigo, mostrando-me além de seu conhecimento e experiência científica, o real caminho para a elaboração deste trabalho, incentivando-me cada vez mais a abraçar a carreira docente. 
Ao Prof. Dr. Paulo Amarante de Araújo, pela excelência de pessoa, professorpesquisador e conhecimentos transmitidos.

Ao Prof. Dr. Paulo Afonso Silveira Francisconi pelo exemplo de professor e pela amizade dispensada.

Aos professores da disciplina de Dentística da Faculdade de Odontologia de Bauru - USP, Aquira Ishikiriama, Carlos Eduardo Francischone, Eduardo Batista Franco, João Lúcio Coradazzi, José Carlos Pereira, Maria Fidela de Lima Navarro, Mário Honorato da Silva e Souza Júnior, Ricardo Marins de Carvalho e Rafael Francisco Lia Mondelli pela disposição e atenção com que sempre me receberam.

À Faculdade de Odontologia de Bauru, através de seu diretor Prof. Dr. Aymar Pavarini e de seu vice-diretor Prof. Dr. Clóvis Monteiro Bramante.

Ao Prof. Dr. Luiz Fernando Pegoraro, presidente da comissão de pós-graduação da FOB-USP e Prof. Dr. José Carlos Pereira, vice-presidente da comissão da pósgraduação, pelo desempenho aos cursos oferecidos nesta instituição.

A todos os professores do curso de pós-graduação da Faculdade de Odontologia de Bauru - USP.

Ao Prof. Dr. José Roberto Pereira Lauris, pelo planejamento e análise dos dados obtidos.

Aos professores Arnaldo e Ademir do SENAI - Bauru, pela presteza e atenção demonstrada, durante a confecção de uma peça utilizada no trabalho.

À Southern Dental Industries, S.S.White e Ceramodental, pela doação dos materiais usados nesta pesquisa.

Ao laboratório de Bioquímica pela confecção da solução de sulfeto de sódio a 5 \%, usada neste experimento.

A todos os amigos do curso de pós-graduação, especialmente os de Materiais Dentários, Ana Rita, Élio, Heraldo e Oscar. 
Aos funcionários das disciplinas de Dentística e Materiais Dentários da Faculdade de Odontologia de Bauru: Elizabeth, Ângela, Eloísa, Nelson, Sandra, Lourisvalda e Alcides.

Às funcionárias da pós-graduação da Faculdade de Odontologia de Bauru, Giane, Ana e Cleusa pela amizade e receptividade demonstrada.

Aos funcionários da Biblioteca da Faculdade de Odontologia de Bauru pelo tratamento carinhoso, Maria Helena, Denise, Valéria, Cybelle e Marcelo.

À Faculdade de Odontologia de Lins - UNIMEP, através de seu diretor Prof. Dr. Carlos Wagner de Araújo Werner e a todos os professores desta escola.

Ao Prof. Dr. Osvaldo Benoni Nunes e a Profa. Dra. Nancy Alfieri Nunes, pela grande demonstração de amizade, carinho e dedicação.

Ao Prof. Dr. Mauro Teixeira Villanova, coordenador do curso de Odontologia de São José do Rio Preto/SP - UNIRP, e a todos os professores pela confiança e incentivo.

Para Ana Paula Prado Ferreira pelo apoio e estímulo demonstrados para a conclusão da tese.

Para Leandro Fava dos Santos pela elaboração das figuras e formatação do trabalho.

Ao meu tio Diógenes de Abreu ("in memorian"), exemplo de pessoa, mestre e esportista.

A tia Diva Penha Targa e Abreu, primos e amigos, pela demonstração de carinho e amizade.

Enfim, a todos que de alguma forma contribuíram para a realização deste trabalho, muito obrigado!!!!! 
RESUMO. xiii

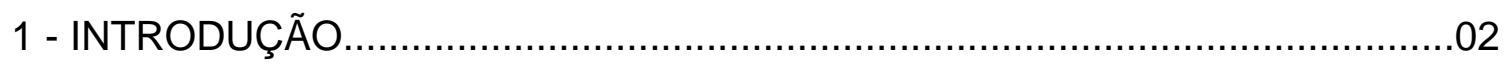

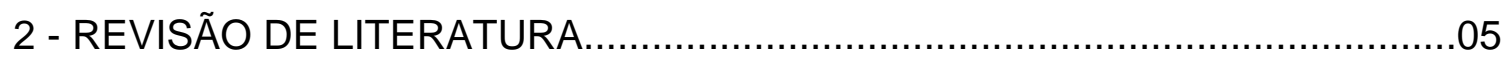

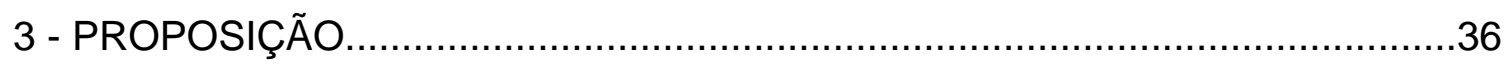

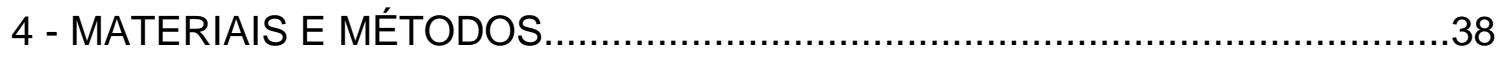

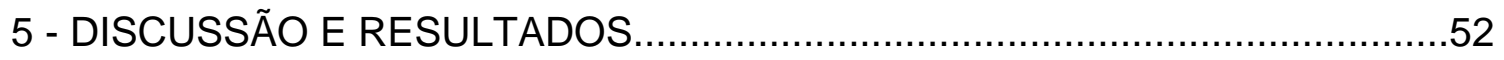

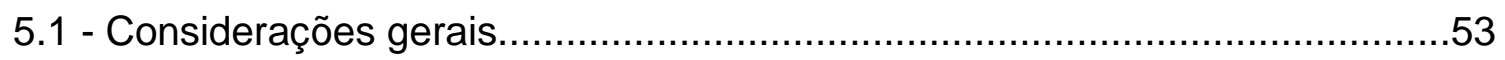

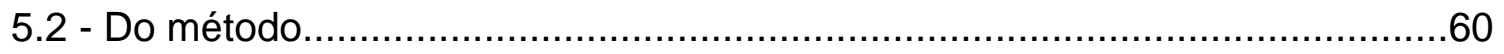

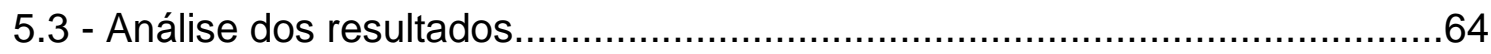

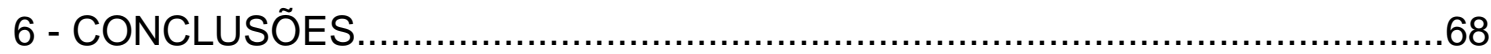

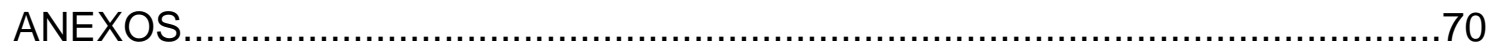

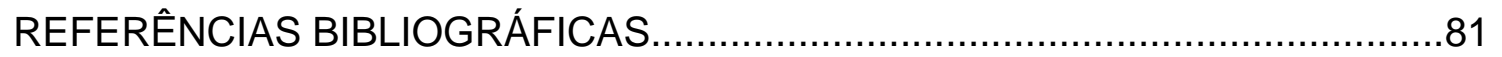

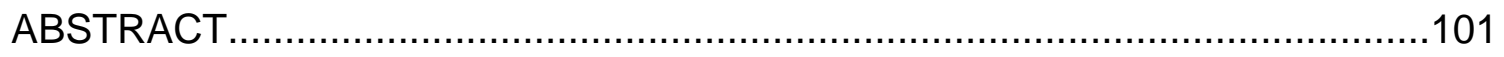


Avaliou-se a resistência à corrosão pelos testes de perda de peso em imersão alternada (solução-ar) e as conseqüentes alterações produzidas nas superfícies dos três materiais restauradores (os amálgamas Dispersalloy e Tytin Plus, ambos de alto conteúdo de cobre, respectivamente do tipo fase dispersa e do tipo partícula única, assim como a liga à base de gálio Galloy), não ou associados a dois sistemas adesivos (All-Bond 2 e PAAMA-2), observadas através da medição da rugosidade de superfície. Confeccionou-se dez corpos-de-prova, para cada condição específica, a partir de uma matriz metálica de aço inoxidável contendo cinco cavidades cilíndricas, com 10,7 mm de diâmetro por 3,0 mm de altura cada uma. Após o polimento, como é feito no caso de análises metalográficas, os espécimes foram pesados e levados ao rugosímetro para realizar as medições imediatamente. Estes foram submetidos à imersão alternada, na solução de sulfeto de sódio a 5 \%, por um período de 24 horas e novamente foi realizada a pesagem e obtidos os valores de perda de peso. Depois da pesagem, os corpos-de-prova foram levados novamente ao rugosímetro para obtenção dos valores médios de rugosidade de superfície. Os resultados foram registrados e submetidos à análise de variância, a dois critérios, e ao teste de contrastes de Tukey-Kramer. Dos resultados obtidos, conclui-se que todos os espécimes perderam peso e tiveram sua rugosidade de superfície aumentada após a imersão em solução corrosiva; a liga Galloy mostrou valores maiores, tanto no método de perda de peso como no de rugosidade de superfície, quando comparada aos dois amálgamas; a liga Tytin Plus alcançou os melhores resultados; houve diferença estatisticamente significante entre os materiais restauradores, mas não entre os sistemas adesivos utilizados, mostrando comportamentos diferentes dependendo da combinação desses fatores.

\section{1 - INTRODUÇÃO}


Amálgama dentário é o material restaurador mais utilizado mundialmente apesar da sua falta de estética e da controvérsia envolvendo o mercúrio, pois nenhuma conclusão evidencia que o amálgama é um perigo biológico, pelo contrário, diversos artigos a respeito ${ }^{25,26,43,97}$ atestam a segurança quando usado devidamente pelos cirurgiões-dentistas. O seu custo, longevidade e facilidade de manipulação faz com que o material seja usado na Odontologia há pouco menos de 200 anos $^{17,18}$. Atualmente as ligas para amálgama mais empregadas são aquelas que apresentam alto conteúdo de cobre por apresentarem melhores propriedades como redução da corrosão, manutenção do polimento superficial, melhor integridade marginal, baixos valores de "creep" e melhor resistência mecânica ${ }^{5,12}$.

Após o condicionamento ácido do esmalte preconizada por BUONOCORE $^{11}$, em 1955, VARGA; MATSUMURA; MASUHARA ${ }^{93}$ (1986) introduziram a técnica do amálgama com adesivo, a qual mostrava vantagens como retenção melhorada, diminuição da infiltração nas margens da restauração e possível reforço do dente. Contudo, estudos ${ }^{1,68}$ relatam problemas da incorporação de resina ao amálgama podendo causar uma diminuição na resistência à compressão da restauração, técnica operatória mais complicada e com poucas vantagens evidentes sobre a técnica tradicional da colocação do amálgama na cavidade.

A liga à base de gálio foi introduzida em 1928, segundo SMITH; CAUL ${ }^{84} \mathrm{e}$ WATERSTRAT ${ }^{98}$ como parte de um material para restauração dentária. Alguns trabalhos $^{84,85}$ foram relatados, por volta de 1950, utilizando essa liga de gálio como material restaurador como uma alternativa e substituição ao amálgama. Vários aspectos foram examinados como as propriedades mecânicas ${ }^{8,49,61}$, manipulação ${ }^{46}$, toxicidade ${ }^{13,47,76}$ microestrutura ${ }^{67}$ e desempenho clínico ${ }^{36,57,101}$. Os dados de laboratório ${ }^{1}$ indicam satisfatoriamente para o uso clínico, mas os dados clínicos mostram uma alta corrosão ${ }^{36,57,58}$ das ligas de gálio, desenvolvendo manchas nas margens deteriorando as restaurações. Além do mais, outras pesquisas $^{46,57}$ demonstraram grandes fraturas em dentes restaurados, altas 
porcentagens de sensibilidade pós-operatória ${ }^{57,58}$ e complicações pulpares ${ }^{58,64,65}$ indicando que as ligas de gálio são dimensionalmente instáveis sob certas condições.

A característica de resistir à oxidação e corrosão das ligas metálicas utilizadas na cavidade oral tem sido talvez a maior preocupação dos pesquisadores em encontrar um sistema de liga que apresente resultados satisfatórios. Seguindo-se uma técnica criteriosa de acabamento e polimento ${ }^{9,95}$ das restaurações, tanto para as de amálgama como para as de ligas de gálio, surgirão melhores características superficiais nas ligas metálicas a fim de que venham a oferecer maior resistência à oxidação e corrosão, quando submetidos aos meios considerados agressivos, principalmente nos pacientes com má higiene oral. O ânion sulfídrico ingerido através de alimentos (cebola, ovos, feijão etc) ou ainda liberado pela atividade microbiana, faz com que este meio se torne menos resistente à corrosão destas ligas. Acontece semelhantemente em relação ao ácido cítrico (sucos cítricos), fosfórico (refrigerantes), cloreto de sódio e potássio, que também fazem parte da alimentação. A superfície metálica lisa e polida resulta em maior possibilidade e facilidade de higienização, dificultando o acúmulo e retenção de placas bacterianas, bem como preservando os tecidos periodontais adjacentes. Portanto os procedimentos de abrasão e polimento das restaurações são de fundamental importância, sendo considerados como requisitos periodontais e biológicos ${ }^{95}$ necessários como fator determinante para o sucesso clínico.

SWARTZ; PHILLIPS; TANNIR ${ }^{88}$ comentaram da dificuldade clínica de distinção entre manchamento e corrosão das ligas metálicas, conceituando corrosão como um ataque gradual químico e eletroquímico do metal pela atmosfera, umidade e outros agentes e manchamento como a descoloração da superfície metálica devido à formação de uma película de óxidos. Convém salientar que na superfície das ligas forma-se a camada de passivação representada pela formação de uma película podendo protegê-las contra a corrosão. Uma restauração altamente polida tem aumentada grandemente sua resistência à corrosão, pois este polimento resulta em maior resistência aos ataques do meio bucal ${ }^{9}$. 
Em relação à premissa de que as restaurações contendo gálio sofrem uma excessiva expansão, devido à corrosão intrabucal, seria importante através de testes laboratoriais, nos quais analisou-se e determinou-se a resistência à corrosão e oxidação das ligas para amálgama e à base de gálio, sem e com adesivos, através do método de perda ou ganho de peso em imersão alternada, sugerido por TUCCILLO; NIELSEN ${ }^{92}$ e empregado por MONDELLI ${ }^{50}$, com as conseqüentes alterações produzidas nas superfícies das ligas, observadas através da medição da rugosidade de superfície. 
Muitas referências na literatura descrevem estudos de pesquisadores sobre todos os aspectos do amálgama e vários sobre as ligas à base de gálio, servindo como informações importantes para o sucesso das restaurações dentárias com estes materiais. Outra preocupação é em relação à corrosão e manchamento dessas ligas utilizadas em restaurações na cavidade oral, pois a prata pura não se altera pelas salivas ácidas e alcalinas, mas apresenta uma grande afinidade pelo enxofre e mancha rapidamente quando em contato com ovos ou mesmo a atmosfera, enquanto o cobre tem uma grande afinidade pelo oxigênio quando exposto ao ar ou aos fluidos bucais.

O material amálgama foi utilizado pela primeira vez como restaurador de dentes, por volta de $1826^{17,18,86}$ na França, na forma de uma pasta prata-mercúrio, obtida pela mistura de mercúrio com raspas de moedas de prata. Dois pesquisadores, TOWNSEND ${ }^{17,18}$ (1855) e FLAGG ${ }^{17,18}$ (1870) contribuíram muito para a melhora do material, sendo que o primeiro demonstrou que a liga contendo partes iguais de prata e estanho fora superior à liga original de prata-cobre das moedas, enquanto que o segundo mudou a composição para $60 \%$ de prata, $35 \%$ de estanho e $5 \%$ de cobre, obtendo sucesso maior ainda que o primeiro.

No início de 1908, estudos de $\mathrm{BLACK}^{7}$ serviram para mostrar que a composição da liga para amálgama e a maneira de mistura ou manipulação eram importantes no controle da resistência e dureza da massa e contração ou expansão, as quais podem ocorrer durante o processo de endurecimento. Nenhum dos outros estudos feitos nesta época tinha sido tão completo como os desse pesquisador, servindo de base para nossas atuais ligas para amálgama. Ele 
inclusive determinou maneiras com relação à forma e dimensão dos preparos cavitários para receber o material restaurador, sendo até hoje usados os seus princípios.

Uma significante contribuição foi feita nos Estados Unidos em $1929^{17}$, para o maior progresso e estabilização do amálgama na prática dental, pela adoção da Especificação $\mathrm{n}^{0} 1$ da American Dental Association ${ }^{3}$ (A.D.A.) para amálgama como resultado de estudos feitos pelo National Bureau of Standards ${ }^{15}$ (N.B.S.). Pela primeira vez, determinou-se um conjunto de testes uniformes para as propriedades do amálgama e impôs-se limitações sobre a composição da liga. Muitos aperfeiçoamentos na uniformidade de várias ligas para amálgama decorreram da aplicação dessa especificação, resultando em restaurações mais padronizadas, serviços melhores ao paciente e viáveis para o profissional.

PLEASURE $^{74}$ comentou que os fatores que afetam a corrosão dos metais são a composição e estrutura da liga, natureza do meio e a presença de diferentes potenciais elétricos que podem ser internos, devido à heterogeneidade do metal ou externos, tais como contato com outros metais e ligas. Para este autor a corrosão desses metais era devido a processos eletrolíticos.

Em 1938 WILLIAMS $^{100}$ realizou uma revisão de literatura relacionada com as propriedades das ligas e se referiu a alguns fatores associados com os problemas de manchamento e corrosão. Para ele o manchamento pode ser definido como a produção de um fino filme aderente sobre o metal, interferindo com o brilho original e usualmente causando mudança de cor, podendo este filme aumentar o peso da liga. Já a corrosão pode ser definida como a perda de peso de um metal, produzindo uma substância não aderente, e quando o produto for 
removido a peça terá perdido peso. O autor comentou sobre a necessidade do desenvolvimento de testes específicos para análise de corrosão, manchamento ou descoloração para as ligas metálicas.

PHILLIPS $^{69}$ em 1944 relatou que o amálgama era o material restaurador mais suscetível a variações manuais e que, a trituração mecânica quando comparada com a manual, assegurava uma massa geralmente mais consistente e uniforme, com melhores resistências compressivas em 1 e 24 horas, excluindo variações humanas.

Outra afirmação feita por esse pesquisador juntamente com BOYD ${ }^{72}$, é a de que uma das variáveis que estão sob a responsabilidade do profissional é a dosagem liga/mercúrio. Porque, devido aos resultados obtidos em 1947 concluíram que quanto mais mercúrio usado na massa, menor era a resistência e que esta queda foi notada mais em 1 hora que em 24 horas, indicando que todo profissional deveria observar a dosagem certa da relação liga/mercúrio, recomendada nas instruções do fabricante, resultando em uma restauração mais resistente.

Uma conclusão feita por PHILLIPS ${ }^{70}$ em 1949, foi que a resistência compressiva foi baixa nas primeiras horas, aumentando até alcançar $85 \%$ do total nas primeiras 8 horas e aumentando ainda mais até 6 meses, e de que não houve diferença estatística significante entre os valores das resistências dos corpos-deprova armazenados em estufa a $37^{\circ} \mathrm{C}$ e em saliva artificial na mesma temperatura.

Como atrativo alternativo do mercúrio o uso do gálio foi sugerido na década de 1920 , por PUTTKAMMER ${ }^{84,98}$. Com esta preocupação, SMITH; CAUL $^{84}$ começaram a pesquisar o elemento químico gálio, predito por MENDELEEFF ${ }^{84} \mathrm{em}$ 
1871. Este metal tem várias propriedades físicas importantes como ponto de fusão de $29,78^{\circ} \mathrm{C}$, ao passo que seu ponto de ebulição é de $1983^{\circ} \mathrm{C}$, sendo portanto uma das mais longas variações líquidas para os metais e podendo ser indicado em lugar do mercúrio como componente de um material restaurador.

Uma investigação sobre o material gálio por SMITH; CAUL; SWEENEY ${ }^{85}$ em 1956, mostrou que o sistema de gálio-cobre-estanho teve propriedades físicas que permitiam seu uso em restaurações dentais. Sua dureza e resistência foram iguais e em alguns ensaios, maiores que as do amálgama de prata convencional usado para restaurações dentárias. Concluíram então que as ligas Ga-Cu poderiam ser promissoras para uso como material restaurador bucal, devendo ser completados com estudos mais avançados envolvendo resistência à corrosão, teste biológico e avaliação clínica para serem recomendados para utilização na clínica geral.

SWARTZ; PHILLIPS; TANNIR ${ }^{88}$, no ano de 1958, relataram que os grandes problemas das restaurações metálicas são a oxidação e a corrosão. Esta tem sido definida como um ataque gradual químico e eletroquímico do metal pela atmosfera, umidade e outros agentes, enquanto a oxidação ou manchamento seria a descoloração da superfície metálica devido à formação de uma película de óxidos. Sendo difícil a distinção clínica entre o manchamento e a corrosão, tais termos vêm com freqüência sendo usados indiferentemente na literatura odontológica.

Conceituando corrosão, BRAGA $^{9}$ (1959), considera como o ataque da superfície de um metal pelo meio no qual ele se encontra, podendo ser causado pela reação direta entre o metal e o oxigênio ou pelo fluxo de uma corrente 
elétrica. Muitas vezes, forma-se uma película na superfície das restaurações que as protege de corrosão posterior, sendo que este fenômeno é conhecido com o nome de passividade. Uma restauração altamente polida pode ter aumentada grandemente sua resistência à corrosão, pois este polimento resulta em uma camada homogênea resistente aos ataques do meio bucal, podendo esta manchar-se ligeiramente sem contudo sofrer corrosão. Porém, se o polimento não for uniforme em toda a superfície metálica, a área não polida formará um par elétrico com a área polida, resultando no aparecimento de manchas e até mesmo corrosão destas áreas.

Em 1962 aconteceu um marco determinante, na evolução do amálgama dental quando DEMAREE e TAYLOR ${ }^{52}$ confeccionaram um novo formato de partícula, através de nebulização (atomização) da liga no estado líquido obtendo partículas esferoidais. As ligas para amálgama com essas partículas têm apresentado restaurações com maior resistência à compressão, tração, como também resistência marginal superior, quando comparadas com as ligas de limalha.

Com o intuito de melhorar a resistência à compressão do amálgama, INNES; YOUDELIS ${ }^{33}$ (respectivamente, um dentista e um engenheiro metalurgista canadenses) introduziram na Odontologia, em 1963 uma nova e importante modificação no material, que foi a adição ao pó (em forma de limalha da liga convencional prata-estanho) de uma certa quantidade de partículas esferoidais de uma liga prata-cobre, mecanismo que é denominado de dispersão. Os resultados determinaram um grande aumento na resistência e diversas melhoras nas propriedades do material. Contraditoriamente à exigência da Especificação $n^{0} 1$ da 
A.D.A. ${ }^{3}$, a quantidade de cobre nessa liga nova passou a ser bem maior que $6 \%$, a qual passou a ser chamada de liga de alto conteúdo de cobre, ou enriquecidas com $\mathrm{Cu}$ ou "non gama-2", isto porque há eliminação da fase gama-2, caracterizada por ter fraca resistência à compressão e à corrosão.

Segundo VIEIRA ${ }^{95}$, o fenômeno de corrosão é decorrente da ação de agentes externos, tais como o ar, água salina, solo, ou soluções ácidas ou alcalinas, sendo os metais sujeitos a uma destruição gradual e progressiva, que iniciando-se na superfície faz com que seu aspecto externo se modifique. A magnitude da corrosão depende de fatores tais como a natureza do metal, composição e estrutura das ligas, natureza de agentes químicos do meio circundante, porcentagem de agentes nocivos que contém (oxigênio, umidade, ácido ou bases) e da temperatura. A corrosão pode ser uniformemente distribuída pela superfície metálica ou localizar-se em determinadas áreas, as quais sofrem corrosão de maior intensidade podendo ser seletiva, quando ataca apenas alguns dos constituintes de uma estrutura ou intercristalina, quando verifica-se sua propagação através dos limites granulares.

Preocupados com as ligas de gálio-paládio e gálio-ouro tiveram seu uso clínico restringido por falta de informações adequadas relativas à resposta biológica. LYON et al. $^{43}$ (1966) implantaram sub-cutaneamente, em ratos de laboratório, cilindros de amálgama de prata e cilindros de liga gálio-ouro, sendo que após 6 meses encontraram uma resposta mínima ao amálgama implantado servindo como controle. Em contrapartida, as ligas gálio-ouro causaram uma resposta severa de corpo estranho (fibrose) no tecido de origem. Além disso, os cilindros de gálio-ouro fragmentaram e desintegraram parcialmente. 
Em um trabalho realizado por WATERSTRAT ${ }^{98}$, em 1969, ficou evidente que as ligas de gálio-paládio-estanho possuíam muitas das propriedades desejáveis para um material restaurador dental. Quando comparadas ao amálgama dental, obtiveram resistência superior e maior ainda quando sob uma aplicação de carga à temperatura da boca. Observou que aquelas ligas possuíam um coeficiente de expansão térmica próximo ao dente humano e que molhavam efetivamente a estrutura dentária produzindo com isso, um selamento marginal mais eficaz que o usualmente obtido pelo amálgama de prata. Chegou à conclusão de que as ligas de gálio-paládio-estanho oferecem várias vantagens significantes sobre o amálgama dental como material restaurador, porém para usá-lo clinicamente, deverá haver um estudo mais extenso de suas propriedades biológicas.

A definição de oxidação apresentada por TUCCILLO; NIELSEN ${ }^{92}$, em 1971, caracteriza-se como sendo uma descoloração detectável visivelmente na suprefície do metal, formada por uma fina camada aderente de óxidos ou sulfetos, induzidos pela reação química entre metal e ambiente. Para testar a resistência à oxidação das ligas estudadas, os autores desenvolveram um aparelho especial que permitia a imersão alternada dos corpos-de-prova, com velocidade de 1 rotação por minuto proporcionando uma imersão de 15 segundos dos espécimes em saliva artificial ou solução de sulfeto de sódio a 0,5 \% e exposição ao ar por 45 segundos.

Em 1973, FICHMAN; SILVA; GUIDI ${ }^{26}$ estudaram diversos tipos de dispensadores de limalha e mercúrio que, além da pouca variabilidade, 
comportaram-se bem, sendo então usados para a dosagem das partes constituintes para obtenção do amálgama.

ASGAR $^{4}$ introduziu em 1974 um novo tipo de liga para amálgama, com alto conteúdo de cobre de composição simples (partícula única), de forma esferoidal enriquecida com cobre, onde não há formação da fase gama-2.

As propriedades adesiva e seladora de uma liga com gálio-paládio-estanho foram investigadas a nível de esmalte e dentina, em comparação às ligas tipo "fine-cut" e esferoidal, por SAITO; FUSAYAMA ${ }^{80}$ em 1975. Verificou-se na propriedade adesiva que o amálgama dental não mostrou nenhuma adesão, ao passo que a liga com gálio revelou várias magnitudes de adesão comportando-se da seguinte maneira: foram maiores para esmalte que para dentina; para massa molhada (proporção 1:0,50) que a padrão $(1: 0,43)$; para a temperatura da sala que a da boca e em ar mais seco (50\% umidade) que em ar úmido (umidade saturada) ou em água. Quanto aos testes de selamento, a penetração de corantes foi menor com a liga com gálio que os dois amálgamas, com a massa molhada que a padrão e à temperatura da sala que à temperatura da boca.

A influência da técnica de condensação em algumas propriedades físicas de amálgamas foi estudada por VILLELA; GALAN JUNIOR.; MONDELLI ${ }^{96}$ em 1979, onde concluíram que houve diferenças significantes entre as partículas das ligas e entre tempos (1 e 24 horas), contudo não apresentaram diferenças entre as duas técnicas de condensação (manual e mecânica) sobre a resistência à compressão do amálgama.

GALANTE $^{27}$, no mesmo ano, concordou com outros trabalhos de PHILLIPS ${ }^{69,70}$, que não havia diferenças entre amalgamação manual e mecânica, 
desde que feitas corretamente, tendo vantagens na segunda pela uniformização da massa e rapidez de obtenção da mesma.

BARATIERI et al. ${ }^{5}$ em 1984, mostraram as vantagens e desvantagens entre o uso do amálgama de composição convencional e do enriquecido com cobre. Dentre as vantagens do último sobre o primeiro, apresentavam menos fase gama2 , portanto maior resistência de borda e à corrosão, necessitavam menor quantidade de mercúrio para a trituração, menor alteração dimensional e menor "creep". Como desvantagens, apresentaram menor resistência à tração e custo maior. Concluíram que o melhor critério para seleção de uma liga é observar os resultados de pesquisas clínicas e que todo profissional deveria utilizar ligas enriquecidas com cobre.

No seu livro texto, PHILLIPS ${ }^{71}$, comentou que os metais sofrem reações químicas com os elementos não metálicos do meio, produzindo compostos químicos comumente conhecidos como produtos de corrosão, sendo que tais compostos podem acelerar, retardar ou não ter qualquer influência na deterioração posterior da superfície metálica. Mesmo havendo uma diferença técnica definida, fica clinicamente difícil distinguir os fenômenos de mancha e corrosão, sendo estes termos utilizados indistintamente em Odontologia. O autor descreve a mancha como sendo a descoloração superficial de um metal, ou mesmo uma ligeira perda ou alteração do brilho superficial. Na cavidade bucal a mancha ocorre pela formação de depósitos moles e duros na superfície da restauração. A mancha resulta de bactérias produtoras de pigmentos, drogas contendo agentes químicos como o ferro ou mercúrio e detritos alimentares adsorvidos. Já a corrrosão se divide em química e eletroquímica, não é meramente um depósito 
superficial e sim uma deterioração real de um metal que reagiu com elementos do seu ambiente.

BRANNSTRÖM; ASTRÖM ${ }^{10}$ lançaram a hipótese que a ação hidrodinâmica do fluido dos túbulos dentinários e no espaço entre amálgama e estrutura dentária pode conduzir à sensibilidade pós-operatória. Chegaram à conclusão de que se os túbulos dentinários fossem realmente selados pelo adesivo, a sensibilidade pósoperatória poderia ser reduzida ou eliminada.

Pela primeira vez VARGA; MATSUMURA; MASUHARA ${ }^{93}$ estudaram em 1986, a possibilidade de união do amálgama à estrutura dental através de materiais adesivos, como a resina 4-META "metacriloxietil trimetílico" (Parkell) e o Panavia Ex (Kuraray), avaliando-os quanto à microinfiltração. De acordo com os resultados, o experimento pioneiro com "amálgama adesivo" revelou que o uso de adesivos diminuiu a infiltração marginal, em restaurações de amálgama.

Na mesma época, SHIMIZU; UI; KAWAKAMI ${ }^{83}$ empregaram um adesivo resinoso, com o objetivo de unir o amálgama à estrutura dental, através da técnica do condicionamento ácido, preconizado por BUONOCORE ${ }^{11}$, possibilitando uma maior retenção das restaurações e maior preservação de remanescente dental sadio, sugerindo ser a técnica adesiva clinicamente efetiva.

Uma avaliação da toxicidade da liga de gálio patenteada por OKAMOTO; HORIBE; YAMAMOTO ${ }^{62}$ obteve dados para enquadrá-la como uma substância comum de acordo com a classificação das leis farmacêuticas do Japão. MASUHARA; NAKAMURA; KUWASHIMA ${ }^{47}$ em 1987, através de testes apropriados mostraram a segurança clínica destas ligas. 
Em 1988, STANINEC; HOLT ${ }^{87}$ desenvolveram uma técnica onde mostraram que o amálgama pode ser aderido ao esmalte e à dentina atacados por ácido, por intermédio de um forramento adesivo. Afirmaram também que tais técnicas não apenas inibiram a microinfiltração como também permitiram a redução das dimensões do preparo cavitário, providenciando suporte intracoronário de cúspides frágeis, aumentando-lhes a resistência à fratura, permitindo portanto, restaurações de amálgama rápidas e conservadoras de dentes para os quais previamente seriam indicadas restaurações fundidas. Postularam a existência de uma adesão mecânica e iônica entre a superfície atacada do dente e a resina adesiva e uma retenção mecânica e adesão através de forças de Van der Waals entre a resina adesiva e o amálgama.

Numa pesquisa feita por STANINEC ${ }^{86}$ em 1989, na qual testou a técnica do amálgama adesivo em preparos cavitários sem retenção, comparando às restaurações de amálgama com retenção adicional sob simulação de carga oclusal, chegou à conclusão de que tal técnica usando um adesivo de resina, foi mais efetiva que o uso de uma canaleta proximal ou de cauda de andorinha oclusal, prevenindo assim a resistência ao deslocamento sob simulação de carga oclusal.

No mesmo ano LACY; STANINEC ${ }^{40}$ mostraram as vantagens do amálgama com adesivo como diminuição da necessidade de retenção mecânica pelo uso da técnica do ataque ácido e maior conservação da estrutura dental por preparos cavitários não tradicionais, tratando-se de preparos mais conservativos. Disseram que o desempenho deste tipo de restauração a longo tempo deveria ser analisada, 
mas que pelas pesquisas iniciais e pelas propriedades conhecidas dos materiais envolvidos, seria promissor.

Um estudo clínico feito com uma liga experimental de gálio por YAMASHITA; ITOH; WAKUMOTO ${ }^{101}$ em 1989, foi observada uma diminuição da estabilidade marginal e resistência à corrosão do material após 1 ano de uso.

Em 1990, HAGIWARA et al. ${ }^{31}$ pesquisaram a mutabilidade das ligas de gálio, onde observaram que não tinham qualquer mudança no DNA e que não houve presença de colônias marcadas ao redor das partículas das ligas de gálio, demonstrando dessa forma que estas ligas não eram mutagênicas.

Em estudos feitos no ano seguinte, com cápsulas para verificação de teores de vazamento de mercúrio nas mesmas, ficou constatado por NASCIMENTO et al. ${ }^{56}$, que as cápsulas rosqueáveis, tanto reutilizáveis e descartáveis, usadas novamente, apresentaram valores maiores de vazamento, e que portanto não deveriam ser reutilizadas. Outro resultado obtido foi de que vazaram quantidades significantemente menores de mercúrio das cápsulas reutilizáveis com tampa lisa. Estes resultados mostraram que as normas de segurança e higiene de trabalho, estabelecidas com base em dados de pesquisa, deveriam ser seguidas por todos os que trabalham com amálgama.

OKABE; WOLDU; NAKAJIMA ${ }^{59}$, na mesma época, estudando a liga de gálio para restaurações dentais, notaram que a massa solidifica-se em um período curto de tempo da mesma maneira que o amálgama e que a maior resistência esteve entre 1 e 3 horas. Mostraram também que a resistência e "creep" foram similares às ligas para amálgama com alto conteúdo de cobre. 
Várias propriedades físicas foram avaliadas por OKAMOTO; HORIBE ${ }^{61}$ onde observaram que a resistência à compressão da liga com gálio aumentou imediatamente após a mistura, o polimento pôde ser dado no mesmo dia e um bom selamento marginal poderia ser esperado. Constataram também que a técnica para restauração com gálio é mais simples e mais rápida que a de amálgamas, e que estes materiais podem ser úteis na Odontopediatria, onde tratamentos extensos são feitos freqüentemente sob anestesia geral.

ENDO; OHNO; $\mathrm{OKABE}^{24}$ (1991) relataram que embora as ligas de gálio possuíam propriedades mecânicas desejáveis para uso como material restaurador dentário, ainda apresentavam problemas com sua resistência à corrosão. Os pesquisadores realizaram o estudo utilizando Gallium Alloy GF (Tokurili Honten), Tytin (Kerr), Dispersalloy (J\&J) e Velvalloy (Kerr) e verificaram que a liga de gálio teve uma média de corrosão maior que as outras ligas para amálgama.

No trabalho de KAWAKAMI; STANINEC ${ }^{37}$, ainda no ano de 1991 feito com amálgamas adicionados por vários adesivos tais como, All-Bond (Bisco), Amalgambond (Parkell), Panavia (Kuraray), Protobond (Kuraray) e Superbond C\&B (Sun Medical), segundo análise dos resultados dos valores das resistências, observaram diferenças significantes entre a adesão para amálgamas com adesivos e que estes seriam comparáveis aos compósitos, com relação à união do material à dentina.

TRUSHKOWSKY91 sugere em 1991 uma restauração de amálgama com adesivo Amalgambond (Parkell) como alternativa a casos previamente indicados como restaurações metálico fundidas, com a intenção de eliminar ou reduzir 
grandemente alguns sintomas pulpares e obter uma restauração mais conservativa e menos extensa.

Testando a força de união e o grau de microinfiltração do Amalgambond (Parkell), produto que contém 4-META, COOLEY; TSENG; BARKMEIER ${ }^{16}$ obtiveram como resultado significante um grau menor de infiltração.

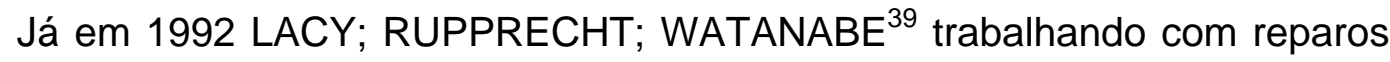
em restaurações de amálgama, observaram que o uso dos adesivos Panavia (Kuraray) e Superbond C\&B (Sun Medical) não melhorou a resistência de adesão entre o amálgama preparado com limalha velha ou nova, principalmente porque não houve adesão evidente da resina à superfície previamente preparada do amálgama com limalha velha.

JORDAN; SUZUKI; BALANKO ${ }^{34}$ em 1992, descreveram a recente introdução dos materiais adesivos para amálgama, tais como Amalgambond (Parkell) e All Bond (Liner F) da Bisco, permitindo aos principais profissionais executar o amálgama, repará-los e unir às restaurações já existentes. Em uma pesquisa envolvendo pré-molares e molares com a cúspide vestibular ou lingual fraturada em associação com restaurações de amálgama pré-existentes, foram reparadas com amálgama novo usando adesivo Amalgambond. Após um ano de observação, nenhuma falha foi observada.

Em 1992 EAKLE; STANINEC; LACY ${ }^{22}$ avaliaram em laboratório os dentes restaurados com amálgama com adesivo Panavia (Kuraray), observando que estes tiveram maior resistência à fratura que aqueles dentes restaurados com amálgama de forma tradicional. 
Num trabalho de TEMPLE-SMITHSON; CAUSTON; MARSHALL ${ }^{90}$ no mesmo ano, foram selecionados 40 dentes e restaurados com amálgama usando verniz, pinos, Amalgambond (Parkell) ou Panavia-Ex (Kuraray). Segundo os resultados, indicaram que os tipos de restaurações com Panavia-Ex e Amalgambond tiveram vantagens significantes sobre as restaurações a pinos, com relação ao tipo de falhas e energia para deslocá-las, principalmente onde a polpa esteve comprometida. Contudo, o sistema retentivo desses dois grupos mostrou ser uma técnica bem sensível.

Com um método "in vitro", descrito em 1992 por ENGLE et al. ${ }^{25}$, foi quantificado o vapor de mercúrio liberado durante procedimentos dentários associados com amálgama, mostrando que expõe potencialmente o paciente e operador. Todavia, a quantidade total de mercúrio liberado durante qualquer procedimento, foi inferior ao nível do total de exposição, calculado diariamente, dos limites estabelecidos pelos órgãos reguladores.

Comparando a toxicidade de uma liga de gálio com ligas para amálgama, PSARRAS; WENNBERG; DÉRAND ${ }^{76}$ na mesma época, não encontraram maiores diferenças entre as várias ligas, encorajando assim estudos e desenvolvimentos sobre as ligas de gálio, as quais são livres de mercúrio.

MILLER et al. ${ }^{48}$ em 1992 compararam a força de união entre a dentina e duas ligas para amálgama com alto conteúdo de cobre e uma a base de gálio usando Amalgambond (Parkell). Verificou-se uma baixa resistência de união na interface amálgama-Amalgambond, portanto não podendo o adesivo ser um artifício confiável no aumento da retenção das restaurações com amálgama. 
Em 1992 NAKABAYASHI; WATANABE; GENDUSA ${ }^{53}$ realizaram estudos com resinas em dentina de bovinos pré-tratada em solução aquosa de ácido cítrico a $10 \%$ e cloreto férrico a $3 \%$. Esta solução removeu a "smear layer" e desmineralizou a dentina, expondo colágeno. Melhores resistências adesivas foram conseguidas com o "primer", sendo que exames com o microscópio eletrônico de varredura revelaram uma formação de zona transitória de resinareforçada-dentina (camada híbrida). O monômero do adesivo impregnou as fibrilas do colágeno expostas e, em polimerização tornou-se embricado com estas para criar uma camada híbrida, essencial para alcançar uma resistência adesiva alta. Observaram então que o "primer" aumentou a capacidade de penetração nos substratos da dentina e que após polimerização e formação da camada híbrida, amálgama, resina acrílica autopolimerizável e compósitos fotopolimerizáveis foram todos capazes de aderir à dentina, concluindo que a resina 4-META/MMA-TBB ( 4 metacriloxietil trimetílico anidro/metil metacrilato iniciado por tri-n-butil borano) criou adesão significante à dentina bovina.

AL-DUNAIRI; HADI-HANOV² em 1993 utilizaram a técnica do amálgama com adesivo Panavia (Kuraray) mostrando melhor adesão da restauração à estrutura dentária, minimizando a necessidade de retenções mecânicas tais como canaletas, desgastes ou cauda de andorinha. Relataram também que esta técnica abria passagem ao desenvolvimento de materiais restauradores que pudessem aderir quimicamente ao dente, preservar estrutura dentária sadia, selar margens das restaurações e reforçar a resistência à fratura dos dentes restaurados.

Em 1993 DEVLIN ${ }^{21}$ analisou três diferentes adesivos, aplicados ao amálgama; utilizou Panavia Ex (Kuraray), Amalgambond (Parkell) e All-Bond 2 
(Bisco), sendo que com o primeiro ocorreu um deslocamento do fluido resinoso durante a colocação do amálgama. Notou que o segundo (baseado num polímero 4-META/MMA-TBB), formava uma fina camada sob o amálgama, enquanto o último usava um "primer" hidrofílico com uma resina sem carga. Observou que estes agentes produziram clinicamente uma adesão ao amálgama, permitiram uma maior conservação da estrutura dentária e reduziram a microinfiltração

HADAVI et al. $^{29}$ ainda em 1993, estudaram a resistência adesiva em reparos das restaurações com amálgama, notando que os resultados dos testes mostraram que o amálgama reconstituído, com e sem um sistema adesivo (Amalgambond), foram mais frágeis que o amálgama intacto, sugerindo dessa forma uma substituição completa da restauração a um reparo, ao menos que retenções adicionais fossem feitas entre o amálgama novo e velho.

Em uma publicação de 1993, DENEHY ${ }^{19}$ indica a colocação de adesivos em todos os casos em que os preparos para restaurações de amálgama encontram-se amplos e com pouca estrutura dentária remanescente. Ainda que esta técnica necessite mais paciência, tempo e maior custo para realizar a restauração, seus resultados são satisfatórios.

Em uma pesquisa sobre o comportamento e estrutura da liga de gálio, OSHIDA; MOORE ${ }^{67}$ em 1993 verificaram através da difração de transmissão de elétrons (TED), que uma liga de gálio e outra liga de gálio, agora junto com uma liga dental com alto conteúdo de cobre mostrou densidade de corrente anódica $10^{3}$ - $10^{4}$ vezes mais que uma liga para amálgama de alto conteúdo de cobre sozinha, determinando que a liga de gálio é mais propensa à corrosão, formando produtos como $\mathrm{Ga}_{2} \mathrm{O}_{3}$ e $\mathrm{SnO}_{2}$ (óxidos de gálio e estanho, respectivamente). 
Analisando as características de manipulação da liga de gálio para restauração dental em 1993, MASH et al. ${ }^{46}$ perceberam clinicamente que o amálgama (Tytin) foi significantemente melhor que a liga de gálio, em cada categoria de manuseio avaliada. A maior diferença entre os dois materiais foi para a colocação e condensação, nas quais a liga de gálio foi classificada de pobre a muito pobre. Nos critérios remanescentes, capacidade de produzir contatos proximais, produzir anatomia oclusal, resistência à fratura na remoção da matriz, lisura superficial e integridade marginal, foi considerada razoável a bom. Segundo o trabalho, a liga deve ser melhorada com modificações nas características de colocação e condensação.

Um estudo realizado por LIA et al. ${ }^{42}$ (1994) em que verificaram o efeito do tratamento do amálgama com um agente desoxidante através de testes de corrosão "in vitro" com ensaios de perda e ganho de peso. Para isso, corpos-deprova obtidos com os amálgamas Velvalloy e Dispersalloy foram submetidos à imersão alternada em solução de sulfeto de sódio a 1 \% por períodos de 24 e 48 horas. Observaram que não houve influência estatisticamente significante do agente desoxidante sobre o índice de corrosão das ligas para amálgama testadas, sendo que a liga Dispersalloy apresentou uma resistência superior. Também relataram uma tendência à diminuição do índice de corrosão com o passar do tempo.

HADAVI et al. $^{30}$ relataram que o uso de um sistema adesivo em restaurações com amálgama oferece uma opção para melhorar a união entre o amálgama e dentina, pois segundo a pesquisa observaram mais alta resistência 
adesiva com All-Bond 2 (Bisco), quando comparada aos espécimes com Amalgambond Plus (Parkell) ou pinos intradentinários TMS.

LEINFELDER ${ }^{41}$ em 1994 relatou que a liga de gálio, não contendo mercúrio, surgiu a 30 anos atrás. Muitas de suas propriedades físicas e mecânicas como alteração dimensional e resistência à compressão são semelhantes ao amálgama tradicional, mas sugere estudos clínicos mais longos e mais específicos para tornar-se uma alternativa restauradora.

O estudo realizado por NAKAJIMA; HORASAWA; OKABE ${ }^{54}$ investigou a estabilidade química do gálio em água e soluções salinas nas concentrações de 0,01 \%, 0,1 \% e $1 \%$ de $\mathrm{NaCl}$ nos períodos de 1, 7 e 28 dias, para obter dados sobre o mecanismo de corrosão das ligas à base de gálio. 0 gálio em água pareceu precipitar sobre a superfície dos espécimes em forma de produtos de reação, possivelmente óxidos de gálio e/ou hidróxido de gálio. A estabilidade química do gálio foi fortemente afetada pela presença de íons $\mathrm{Cl}^{-}$na solução aquosa.

No mesmo período BERRY;NICHOLSON;TROENDLE ${ }^{6}$ comentaram que o amálgama é um material valioso e de baixo custo para os pacientes, permanecendo por um tempo longo na cavidade bucal comparado a outros materiais restauradores. Entretanto, uma nova liga Galloy (SDI) demonstrou características físicas semelhantes ao Dispersalloy (J\&J), Tytin (Kerr) e Permite (SDI), como resistências à compressão e à tração diametral ${ }^{49}$.

MILLER et al. $^{49}$ em 1994 trabalhando com ligas de gálio referente às propriedades físicas e mecânicas, verificou que a resistência da liga Galloy (SDI Austrália) foi significantemente inferior na primeira hora, mas após 7 dias foi maior 
que a liga Gallium Alloy GF (Tokuriki Honten - Japan). Não houve diferenças entre as ligas com relação ao "creep", contudo apresentaram diferenças significantes no que tange à alteração dimensional.

Um trabalho publicado por JORGENSEN et al. ${ }^{35}$ comparando duas ligas de gálio com e sem paládio, quanto às propriedades físicas e resistência à corrosão, foi observado que o paládio teve um efeito importante sobre a alteração dimensional durante a cristalização da liga apresentando uma expansão maior que a permitida pela ISO 1559 (0,2\%), enquanto que a liga sem paládio expandiu cerca de 0,08\%. Foi feita uma observação paralela, em que as ligas contendo gálio tiveram resultados de resistência à compressão e "creep" similares às ligas de amálgama de alto conteúdo de cobre.

Comparando a toxicidade dos elementos liberados em 1994, ligas com mercúrio e gálio foram analisadas por WATAHA et al. ${ }^{97}$ após 72 horas, mostrando que o Tytin (Kerr) não revelou dados significativos, mas o Dispersalloy (J\&J) teve valores severos no início, amenizando com a diminuição do Zn (zinco) liberado, e a liga de gálio teve um comportamento moderado pela substancial e permanente liberação de gálio deste material.

Outra pesquisa nessa área com relação à toxicidade dos íons mercúrio, gálio e índio, feita por CHANDLER; MESSER; ELLENDER ${ }^{13}$ em 1994 verificaram que os últimos não apresentaram valores significantes sob as condições do estudo, podendo ser possíveis substitutos do mercúrio em ligas para restaurações, fazendo com que satisfaçam as necessidades clínicas para uso como material restaurador, e sugerindo também que outros níveis de avaliação biológica deverão ser realizados para estes materiais. 
EAKLE et al. $^{23}$ trabalhando com amálgama e liga de gálio com adesivos em 1994, notaram que o Tytin e a liga de gálio, ambos com adesivos Panavia ou AllBond, foram melhores em retenção que as duas ligas com Amalgambond, indicando que os adesivos poderiam ser usados em lugar dos preparos tradicionais para reter o amálgama e a liga de gálio, preservando portanto quantidade considerável de estrutura dentária.

Uma pesquisa realizada por NAKAJIMA; WOLDU; OKABE ${ }^{55}$ (1995) examinou o efeito da solução salina a 0,9\% de $\mathrm{NaCl}$ sobre as propriedades mecânicas (resistência à corrosão e "creep") na liga de gálio Gallium Alloy GF e Tytin nos períodos de 2 ou 12 semanas de estocagem. A resistência da liga de gálio diminuiu durante a imersão na solução salina, provavelmente devido à pobre resistência à corrosão.

OSBORNE et al. ${ }^{66}$, no mesmo ano, compararam o Galloy (SDI) com duas ligas de alto teor de cobre (Dispersalloy e Tytin) em relação à resistência à tração diametral e dureza. As análises estatísticas mostraram que não houve diferença com relação à dureza, mas o Galloy teve sua resistência à tração diametral significantemente maior que as duas ligas para amálgama, pois vários estudos clínicos e de laboratório têm sido realizados para determinar se o sistema restaurador à base de gálio é aceitável e adequado.

OKABE; WOLDU; NAKAJIMA ${ }^{60}$ (1995) verificaram o comportamento de corrosão em solução salina a $0,9 \%$ de $\mathrm{NaCl}$ a $37{ }^{\circ} \mathrm{C}$ das ligas Gallium Alloy GF e Galloy. Embora as medidas eletroquímicas não mostraram diferenças entre as duas ligas, a dissolução de gálio do Galloy foi significantemente menor que a liga Gallium Alloy GF, devido à ausência de paládio na composição do Galloy, 
eliminando dessa forma a dissolução de gálio durante imersão na solução de 0,9 \% de cloreto de sódio.

Na pesquisa realizada por DESCHEPPER et al. ${ }^{20}$, em 1995 , o Galloy foi comparado ao Permite através da polarização anódina em solução de Riger deoxigenada e imersos na solução de Riger normal a $37{ }^{\circ} \mathrm{C}$. Os produtos de corrosão dos testes de imersão foram analisados usando a difração de transmissão eletrônica (TED). Os resultados sugeriram que a liga de gálio pode causar a corrosão acelerada eletroquímica e que esta liga é mais propensa à corrosão que a liga de alto conteúdo de cobre.

Em um estudo comparando a infiltração marginal de restaurações retrógradas com liga de gálio e com liga para amálgama, WHITWORTH; KHAN ${ }^{99}$ em 1995 verificaram que o selamento da primeira foi superior ao do amálgama, que a sua manipulação foi mais difícil, embora dentro dos limites para uso clínico, e que pode ser uma alternativa para o amálgama na cirurgia endodôntica, merecendo investigações posteriores.

HOSOYA; LAUTENSCHLAGER; GREENER ${ }^{32}$ avaliando na mesma linha dos pesquisadores acima, agora comparando além dos dois materiais anteriormente descritos, também com ionômero de vidro e guta-percha, concluindo que estes foram os que tiveram menor e maior infiltração respectivamente, sendo que as ligas de gálio e para amálgama não mostraram diferenças significantes.

No trabalho feito em 1995 sobre as propriedades físicas da liga de gálio como material restaurador, BLAIR;WHITWORTH; $\mathrm{MCCABE}^{8}$ determinaram que esta liga apresentou expansão maior que o Dispersalloy, porém maior que o limite 
padrão fixado pela I.S.O. (International Standard Organization), valor de "creep" maior, e também sem diferença estatística entre as resistências à compressão, sendo somente relatada uma alta diferença entre 1 e 24 horas para cada material, tornando viável como uma alternativa ao amálgama dental, com a ressalva de que haveria de se melhorar as características de manipulação do material antes da aceitação difundida para uso clínico.

Em 1995, MARGRAF; GOMES ${ }^{45}$ apresentaram o "amálgama adesivo" como uma alternativa para restaurações diretas em dentes posteriores e descreveram a aplicação do All-Bond 2 (Bisco), adesivo de quarta geração com caracterísitcas hidrofílicas, apresentando um bom vedamento marginal e reduzindo a sensibilidade pós-operatória.

PEGORARO; MONDELLI ${ }^{68}$ em 1995 utilizando o amálgama com Panavia (Kuraray) e o sistema All-Bond (Bisco) associado ao Panavia, mostraram que não existiu diferença significante nos resultados, salientando a hipótese de que a utilização de adesivos não aumenta a resistência do remanescente dentário restaurado com amálgama.

Com a publicação de seu livro, BUSATO ${ }^{12}$ mostra, após revisão de literatura, alguns casos clínicos descrevendo a técnica restauradora de amálgama utilizando adesivos dentinários, cimentos resinosos e cimento de ionômero de vidro. Demonstram algumas vantagens como melhoria da retenção e aumento do vedamento marginal, com a possibilidade de prolongamento da vida útil da restauração.

RUZICKOVA et al. $^{78}$ em 1996 examinaram a eficiência clínica de restaurações adesivas com All-Bond (Bisco) e não adesivas. Dos dentes tratados 
com adesivo após um ano de acompanhamento, 100\% apresentaram forma anatômica oclusal adequada, 82\% com contorno proximal adequado, 96\% com boa adaptação marginal oclusal, 94\% com boa adaptação marginal proximal, ausência de sensibilidade em 97\% e 96\% com qualidade superficial, sugerindo que esta técnica é adequada, em cavidades tradicionais, tão bem quanto o amálgama sem adesivo.

Após um ano de avaliação clínica de restaurações com adesivos, MAHLER et al. $^{44}$ em 1996 não notaram diferença entre as restaurações sem e com adesivo, com relação à fratura marginal e sensibilidade pós-operatória em uma a duas semanas depois da colocação, verificando sim, uma adição sobre o custo da restauração, aumento do tempo da sessão de atendimento e alguns problemas da técnica, pois o Panavia (Kuraray) sendo um material resinoso incorporava-se ao amálgama, mostrava-se com grande quantidade de agente adesivo nos ângulos das paredes do preparo e nas áreas interproximais, podendo promover acúmulo de placa nestas regiões críticas.

CHANG et al. ${ }^{14}$ examinaram, em 1996, a microinfiltração em restaurações de amálgama com Amalgambond (Parkell), verniz Copalite e sem nenhum tratamento, verificando que o adesivo Amalgambond reduziu grandemente a microinfiltração ao redor de todas as restaurações de amálgama; Dispersalloy com Amalgambond teve menor infiltração e o amálgama Tytin (Kerr) com adesivo o valor mais alto, sendo que não houve infiltração na união do amálgama recente com o já existente.

Em 1996 MOMOl et al. ${ }^{51}$ no intuito de melhorar o manuseio do material a base de gálio, adicionou menos de $5 \mu$ de álcool à mistura melhorando as 
propriedades de manipulação, não alterando as propriedades mecânicas ou a alteração dimensional, concordando com HABU et $a{ }^{28}{ }^{28}$, que também colocou etanol na massa, reduzindo assim a aderência da mistura no interior da cápsula.

OSBORNE; SUMMITT ${ }^{64}$ (1996) avaliaram o desempenho clínico das restaurações à base de liga de gálio, após dois anos, verificando fratura das margens, corrosão, rugosidade de superfície, fratura do dente, fratura do corpo da restauração e qualquer alteração médica ou dentária durante o estudo. Observaram que a liga Galloy poderia ser usada em substituição ao amálgama em certas situações. Este material é muito sensível à umidade, as restaurações deveriam ser protegidas da saliva e/ou do fluido pulpar durante a inserção e nas primeiras horas de pós-operatório.

Uma avaliação clínica feita em 1996 com a liga de gálio Gallium Alloy GF (Tokuriki Honten, Japan) foi realizada por NAVARRO et al. $^{57}$, exibindo altas proporções de corrosão e sensibilidade pós-operatória após 8 meses de acompanhamento, sendo considerada inaceitável para uso clínico, porque 39\% das restaurações da liga de gálio apresentaram sensibilidade e com problemas adicionais como dentes fraturados, fendas e manchas marginais, onde todas as restaurações de gálio foram então trocadas pelas restaurações com Dispersalloy (J\&J).

Seguindo o mesmo estudo ${ }^{57}$ PRAZERES; BALLESTER; SANTOS ${ }^{75}$ também concluíram que Gallium Alloy GF (Tokuriki Honten, Japan) não foi apropriada para uso clínico e que a expansão exagerada e fraturas poderiam ser responsabilizadas pelo aparecimento de dor pós-operatória permanente e/ou crescente. 
Restaurações em dentes decíduos usando liga de gálio, foram feitas por KAGA et al. ${ }^{36}$ em 1996, que observaram grande deterioração devido à corrosão no período de um ano, chegando à conclusão de ter esse material resistência insuficiente à corrosão para servir como material restaurador permanente, mas elogiam esta liga pelos pacientes e profissionais não terem contato com o mercúrio do amálgama e por ser um procedimento mais simples quando comparado à técnica de restauração com resina composta, principalmente em crianças.

VENUGOPALAN; BROOME; LUCAS ${ }^{94}$ (1997) avaliaram a alteração dimensional e produtos de corrosão do Galloy em comparação ao Tytin. Um grupo de ambas ligas foi confeccionado segundo orientações dos respectivos fabricantes. Outro grupo das ligas foi combinado com água (10 ml) durante a fabricação, para simular a contaminação que poderia ocorrer durante condições clínicas. A contaminação da água durante a confecção, no Galloy levou à corrosão e resultou na expansão devido aos produtos de corrosão formados.

A citotoxicidade de duas ligas de gálio Gallium Alloy GF e Galloy, e uma liga para amálgama Tytin foi estudada por ROCKWELL et al. ${ }^{77}$ (1997), em que ficou constatada que não houve diferença nos níveis de citotoxicidade entre as duas ligas de gálio, mas ambas foram sempre mais citotóxicas que Tytin, provavelmente devido à pobre resistência à corrosão das duas ligas de gálio.

TANGSGOOLWATANA et al. ${ }^{89}$ na mesma época, relataram a infiltração nas restaurações de amálgama com adesivos, através de corantes fluorescentes e radioisótopo de ${ }^{45} \mathrm{Ca}$ com auto radiografias. Os materiais adesivos testados (AllBond 2/Resinomer, Amalcoden e Panavia 21) minimizaram a infiltração cervical 
nas ligas para amálgama Tytin e Dispersalloy, freqüentemente ocorrida na interface dente-adesivo. Os resultados mostraram a seguinte ordem do mais para o menos efetivo: All-Bond 2/Resinomer, Panavia 21, Amalcoden e Copalite (grupo controle).

Em 1997 RUZICKOVA et al. ${ }^{79}$ avaliaram o resultado clínico de restaurações adesivas de amálgama com Primer A\&B e All-Bond, por dois anos de acompanhamento. Segundo análise das características das restaurações adesivas com amálgama, houve um desempenho clínico muito satisfatório, tão bom quanto o das restaurações realizadas com amálgama sem adesivos.

PINTO $^{73}$ em 1997 observou que nenhum dos materiais testados, All-Bond 2+Liner F (Bisco), Scothbond Multi Uso Plus (3M), Vitremer (3M), Panavia 21 (Kuraray) e verniz convencional Copalite, foi capaz de eliminar a microinfiltração, em restaurações de amálgama, nos dois períodos de tempo avaliados (1 e 6 meses), nas margens localizadas em esmalte e cemento, concluindo que por enquanto era prematuro recomendar o uso destes agentes adesivos sob restaurações de amálgama, com o objetivo de diminuir a microinfiltração.

Os autores KNIGHT; BERRY ${ }^{38}$ discutiram as características de manuseio, os procedimentos para colocação e ofereceram recomendações para uso de um novo material livre de mercúrio, recentemente introduzido nos Estados Unidos. Concluíram que embora todos os testes clínicos por um longo período não foram completados, este material à base de gálio Galloy (SDI) mostrou ser um grande potencial como uma alternativa ao amálgama dentário tradicional.

ABREU ${ }^{1}$ (1998) verificou a resistência à compressão e à tração diametral, nas idades de 1 e 48 horas, de três materiais restauradores (os amálgamas DFL 
Alloy e Velvalloy, e uma liga à base de gálio Galloy), associados ou não a três sistemas adesivos (All-Bond 2, PAAMA-2 e Resinomer). Dos resultados obtidos, concluiu que o aumento da idade fez elevar os níveis de resistência; houve diferença estatisticamente significante entre os materiais, assim como para as condições sem e com adesivo, nas duas condições propostas; a liga Galloy comportou-se melhor, comparavelmente à Velvalloy, enquanto que a DFL Alloy apresentou os piores resultados.

OSBORNE; SUMMITT ${ }^{65}$ (1999) observaram que os primeiros resultados das restaurações com liga de gálio tiveram um sucesso qualificado, mas após três anos de avaliação, 10 \% dos dentes restaurados sofreram completa ou incompleta fratura dentária, mostrando corrosão em 32 \% das restaurações e rugosidade superficial em 37 \%. Não houve complicações ou alergia nos pacientes. Três dentes fraturados, de um total de 30 restaurações com cavidades tipo classe 1 , pareceria ser desproporcional para aceitá-lo clinicamente. Os pesquisadores sugeriram que o Galloy, usado com duas camadas de adesivo para prevenir a contaminação pela umidade, não seria um material restaurador conveniente ou adequado.

Um trabalho proposto por OSBORNE ${ }^{63}$ (1999) verificou a expansão das ligas de gálio usadas para restauração sob condições similares a encontradas clinicamente, comparando com duas ligas para amálgama. Os resultados mostraram-se semelhantes a outros estudos clínicos, nos quais as ligas de gálio tiveram uma excessiva expansão quando contaminadas e/ou quando colocadas em soluções salinas. 
NEO et al. ${ }^{58}$ (2000) estudaram o desempenho clínico da liga de gálio selada com um sistema adesivo, levando em consideração a sensibilidade pulpar, fratura da restauração e do dente, deterioração marginal e corrosão. Das 65 restaurações com Galloy, vinte e oito tiveram que ser removidas e com a presença da corrosão em muitas dessas restaurações, pois óxidos e cloretos de gálio foram identificados como produtos predominantes. Concluíram que a liga Galloy, selada com PAAMA2, demonstrou um alto índice de insucesso clínico.

Através de um teste de corrosão em laboratório, isto é, um teste de potencial de polarização constante, SARKAR et al. ${ }^{81}$ (2000) foram capazes de simular a corrosão induzida nos materiais restauradores contendo gálio. Observaram expansão excessiva associada com o desenvolvimento de produtos de corrosão. A excessiva expansão causada pela corrosão, acreditaram os autores, contribuiu para a sensibilidade pós-operatória e fratura do dente com o uso deste tipo de material restaurador.

SETCOS; STANINEC; WILSON ${ }^{82}$ (2000) relataram que numerosos estudos "in vitro" demonstraram várias vantagens da técnica do amálgama com adesivo, como por exemplo melhora da retenção, diminuição da microinfiltração e possível reforço do elemento dentário. Contudo, estudos "in vivo" mostraram pequenas vantagens do "amálgama adesivo" em comparação à técnica do amálgama realizada de forma tradicional. 


\section{3 - PROPOSIÇÃO}

Tendo em vista as informações anteriores, resolveu-se verificar a resistência à corrosão e oxidação de ligas metálicas para amálgama e à base de gálio, sem e com adesivos, através dos métodos de perda ou ganho de peso em imersão alternada em uma solução de sulfeto de sódio a 5\%, utilizando-se um aparelho similar ao empregado por TUCCILLO; NIELSEN ${ }^{92}$, e as conseqüentes alterações produzidas nas superfícies das ligas metálicas, determinadas através da medição da rugosidade de superfície.

Através da interpretação de trabalhos que comparam o teste "in vivo" $57,64,65$ com o teste "in vitro"3,5,6,7,8,50, pode-se observar a existência de uma correlação entre os dois testes, que se consegue pré-determinar com bastante margem de confiança o comportamento clínico destas ligas quando utilizadas na cavidade oral.

As informações serão úteis no entendimento da corrosão na expansão excessiva dos materiais restauradores e suas conseqüências clínicas. 


\section{4 - MATERIAL E MÉTODOS}

Os corpos-de-prova em forma de moedas, tanto para os testes de perda de peso e análise rugosimétrica, foram obtidos utilizando-se uma matriz metálica confeccionada em aço inoxidável, (apresentada na figura 1), contendo cinco cavidades do tipo cilíndrico com 10,7 mm de diâmetro por 3,0 mm de altura cada uma. Todos os espécimes, num total de 90 , foram confeccionados em uma sala na qual havia o controle da temperatura de $23 \pm 2{ }^{\circ} \mathrm{C}$ e da umidade relativa do ar (50 $\pm 10 \%$ ), observando-se o cuidado de se alcançar e manter estes índices desde uma hora antes do início dos procedimentos.

As ligas selecionadas para esta pesquisa, duas que eram amálgamas com alto conteúdo de cobre e uma terceira, à base de gálio, encontram-se listadas abaixo, em ordem alfabética de nomes e com algumas de suas características de interesse para o estudo.

1. DISPERSALLOY, fabricada por Dentsply Indústria e Comércio Ltda., Petrópolis, Rio de Janeiro, Brasil, lote 50380, fabricado em 08/1999, com validade de 5 anos, com relação liga/mercúrio de 1:1, embalada em frascos de 30 gramas;

2. GALLOY, fabricada por Southern Dental Industries Ltda. (SDI), Austrália, lote n. 96029, fabricado em 10/1999, com validade até 10/2002, embalada em cápsulas (cada uma contendo 700 mg de pó e 343 mg de liga à base de gálio, com relação respectivamente de 1:0,49), esta por sua vez contidas em caixas com 50 unidades;

3. TYTIN PLUS, fabricada por S. S. White Artigos Dentários Ltda., Rio de Janeiro-RJ, Brasil, lote OOP, fabricado em 11/05/1998 e validade até 
11/05/2008, com relação liga/mercúrio de 1:1, embalada em frascos de 30 gramas.

Os frascos contendo as ligas embaladas em frascos foram sempre movimentados, por 3 segundos antes de sua utilização, para homogeneização do material.

O lote de mercúrio utilizado (Super, comercializado por Super Dentária Napoleão, Rio de Janeiro-RJ), tinha validade até abril de 2001, sendo apresentado em frascos de $100 \mathrm{~g}$. Para facilitar sua medição, este foi transferido para um dosador volumétrico (fabricado por Sybron/Kerr, Estados Unidos da América), cujas porções (como também as da liga) foram controladas por peso, através de uma balança analítica (SAUTER modelo K 1200, fabricada por August Sauter $\mathrm{GmbH}$, Ebingen, Alemanha), com acuidade até centésimo de grama (apresentada na figura 2).

Os corpos-de-prova de amálgama foram confeccionados, pesando-se primeiramente $1,20 \mathrm{~g}$ de liga e depois igual quantia de mercúrio, para ambas as ligas. Cada porção de liga e mercúrio foi colocada, através de um funil plástico, em uma cápsula descartável (apresentada na figura 3), de um outro material (Permite, também da SDI), a qual havia sido obviamente usada apenas uma vez; na presente pesquisa, cada uma destas cápsulas era usada também apenas uma vez. A trituração era efetuada em um aparelho amalgamador (apresentado na figura 4) de alta velocidade (Ultramat 2, da já citada SDI), por 8 segundos. Para cada cápsula da liga de gálio o respectivo lacre era rompido (assim rompendo-se a membrana que separa a liga em pó da liga contendo gálio) antes dela ser levada ao amalgamador; após a trituração, também por 8 segundos, quebrava-se sua ponta e, com o auxílio de uma seringa própria, colocava-se o material diretamente no interior da cavidade da matriz, para confecção de espécimes.

Anteriormente a esses procedimentos, para os corpos-de-prova confeccionados com os agentes adesivos ALL-BOND 2* e PAAMA-2**, a parte interna da matriz era pincelada (com pincel Tigre $\mathrm{n}^{0}$. 000) com isolante de cera P6456 (Hoechst-V, da Dinamarca), dissolvida a 10\% em benzina (benzeno), e 
depois com os respectivos adesivos sendo fotopolimerizado (PAAMA-2), por um aparelho fotopolimerizador (apresentado na figura 4) Visilux 2 (3M), com raios de onda com valores de 450 a 500 nm. por 20 segundos, ou não (ALL-BOND 2), dependendo do tipo de ativação da polimerização.

O adesivo denominado pelo fabricante como de quarta geração PAAMA-2 (SDI), acompanhado no estojo da liga de gálio, foi utilizado segundo orientações do fabricante, ou seja, colocou-se uma gota do "Dentine/Enamel Adhesive" num recipiente próprio e, com um pincel, passou-se uma camada fina nas paredes internas da cavidade da matriz, e fotopolimerizado. A aplicação do adesivo ALLBOND $2^{* *}$ (Bisco), também de quarta geração, consistiu na adição de uma mistura de "Dentin/Enamel Bonding Resin" e do "Pré-Bond Resin", pincelada numa fina camada, no interior da matriz.

(rodapé de página)

* PAAMA-2, fabricado pela Southern Dental Industries Ltda., Austrália, de lote $n^{\circ} 5422764$, com validade até 10/2002.

** All-Bond 2 Universal Adhesive System, fabricado por Bisco Inc., Itasca (II USA), de lote $n^{\circ} 071342$, com validade até $08 / 2000$.

Com o término do movimento da forquilha do amalgamador, após a trituração mecânica, removia-se a cápsula, abria-se a mesma e retirava-se a massa do seu interior. Depois da homogeneização e através do porta-amálgama ou através da seringa própria da liga à base de gálio, a massa obtida era levada e compactada no interior da cavidade da matriz metálica de confecção de

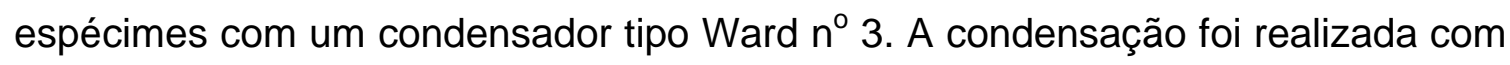
ligeiro excesso, o qual era removido com uma lâmina de bisturi afiada, cinco minutos contados a partir do início da tritutação, utilizando-se um cronômetro (marca Aristo) com marcação de segundos.

Os corpos-de-prova foram alisados, ejetados, pesados na balança Sauter e individualmente envolto em uma gaze, cuidadosamente colocado dentro de um 
frasco de vidro, sem tampa e com uma etiqueta colada contendo a liga utilizada, com ou sem adesivo até o momento do teste de resistência à corrosão e rugosidade superficial, em uma estufa, fabricada por Fanem Ltda., seca e regulada a $37^{\circ} \mathrm{C}$. Os testes foram realizados em idade de 24 horas, utilizando-se 10 corpos-de-prova para cada situação específica. Todos os resultados foram anotados em fichas próprias.

Decorrido esse tempo, os exemplares foram polidos (como se faz no caso de análises metalográficas) através de um desgaste mecânico inicial com lixas d'água com granulação de 600 e 1200 (apresentado na figura 5), irrigadas com água, e depois submetidos a uma politriz Fortel, Struers, da Dinamarca (apresentada na figura 6) contendo pastas abrasivas como óxido de cromo e alumina e Silvo (produto polidor de metais), sendo cada lado do corpo-de-prova polido por 30 segundos com cada lixa e cada um dos feltros, partindo da maior abrasividade para a menor, até que ficassem lisos e brilhantes. Após o polimento, os corpos-de-prova foram escovados com água e sabão, submetidos à limpeza em aparelho de ultra-som (Tempo-Ultrasonic) com água deionizada por 15 segundos e depois mantidos no interior de um dessecador, recipiente este com uma redoma acrílica apresentando na parte de dentro grânulos de cristais de sílica para promover a desumidificação do meio. Depois desses procedimentos, os corpos-de-prova, limpos e secos, foram pesados na balança e levados ao aparelho rugosímetro do fabricante Taylor Hobson Ltda., de modelo Surtronic Roughness Specimen $3^{+}$(apresentado na figura 7), para obtenção das médias aritméticas de rugosidade superficial ( $\mathrm{Ra}$ ) através de quatro medições realizadas na superfície de cada corpo-de-prova, dividindo-se a superfície em 4 partes e escolhendo uma determinada porção da superfície, livre de qualquer defeito estrutural detectável macroscopicamente, num total de 720 medições, antes e após a sua imersão no banho de corrosão com solução de sulfeto de sódio a 5\% por 24 horas em estufa a $37{ }^{\circ} \mathrm{C}$. Esse teste pode ser considerado bastante agressivo, pois além da concentração da solução de sulfeto de sódio a $5 \%$ (produzida pelo laboratório de Bioquímica da Faculdade de Odontologia de 
Bauru), não houve o sistema de auto-limpeza oral realizado com a mastigação, escovação, movimentação da língua e bochecha, que ocorre no caso "in vivo".

E ainda, o rugosímetro foi conectado a um computador com um programa chamado "Talyprof", o qual mostrava os gráficos resultantes das medições e as respectivas rugosidades superficiais em micrometros $(\mu \mathrm{m})$.

Através da visualização esquemática na figura 8 um mecanismo de pressão (entalhes nas bordas periféricas das rodas de resina acrílica) os corpos-de-prova eram presos às rodas de resina acrílica conectadas a um dispositivo especialmente construído para esse ensaio. Esse dispositivo é similar ao usado por TUCCILO; NIELSEN ${ }^{92}$, que permitia girar as rodas de acrílico através de um eixo central movimentando-se lentamente por um pequeno motor elétrico com velocidade reduzida (1 rotação por minuto=r.p.m.) e controlada através de um reostato. Isto permitia uma exposição cíclica ao ar (aproximadamente 45 segundos) e à solução química (aproximadamente 15 segundos) utilizada neste experimento. Os espécimes eram submetidos à imersão e exposição ao ar por 24 horas à temperatura de $37{ }^{\circ} \mathrm{C}$. Isto foi possível colocando o conjunto (dispositivo/corpo-de-prova/solução química) no interior de uma estufa que funcionava como cabine de umidade para o teste de corrosão (apresentado na figura 9).

Após esse período de imersão alternada, os corpos-de-prova eram lavados em água corrente e introduzidos em um aparelho de ultra-som com detergente neutro diluído em água por 15 minutos, para remoção de alguns resíduos em suas superfícies. Foram enxugados com papel absorvente e mantidos no dessecador por mais 15 minutos, sendo a seguir pesados novamente na balança analítica e realizados novos testes de rugosidade superficial.

As diferenças encontradas entre as leituras inicial e final, tanto quanto ao peso e rugosidade superficial dos corpos-de-prova, correspondem aos resultados obtidos e listados das ligas testadas, os quais foram submetidos ao tratamento estatístico, consistindo de análises de variância a 2 critérios de classificação, acompanhadas de comparações individuais pelo teste de Tukey-Kramer, no caso de ter havido significância estatística. 
Em relação aos cuidados do manuseio e toxicidade do mercúrio, várias condutas foram tomadas para preservar a saúde do operador e evitar contaminação do ambiente de trabalho. Os vidros contendo mercúrio, sempre estiveram fechados na armazenagem, sendo toda a manipulação criteriosa, até com uso de luvas descartáveis, em todos os passos da amalgamação. Todas as operações, desde a colocação do amálgama ou liga de gálio na matriz até a ejeção do espécime, foram realizadas dentro de uma bandeja grande, de aço inoxidável com medida de $230 \times 330 \mathrm{~mm}$, por segurança. Durante a condensação do amálgama ou liga de gálio, uma pequena quantidade de mercúrio ou gálio respectivamente, fluía para o espaço vazio no interior do molde e para a porção superior da matriz, sendo despejada dentro de um frasco com fixador radiográfico, com ajuda de uma espátula de Le Cron.

A matriz era colocada dentro de uma bandeja pequena de $130 \times 180 \mathrm{~mm}$, esmaltada branca que permanecia dentro da maior. Removia-se a parte superior da matriz contendo o corpo-de-prova, pegando manualmente o conjunto o qual era invertido e no instante determinado, o espécime era ejetado forçando-o para baixo, sempre executando passos dentro dessa bandeja pequena. Com auxílio de gaze, limpava-se a parte superior da matriz e demais partes com remontagem ficando tudo limpo e pronto para confecção de outros corpos-de-prova, sendo todas as sobras de mercúrio, amálgama, liga de gálio, gaze ou espécimes descartados, colocados no interior do frasco com fixador. 


\section{5 - RESULTADOS E DISCUSSÃO}

\subsection{CONSIDERAÇÕES GERAIS}

Sabe-se que os materiais odontológicos para confeccionar restaurações da estrutura dentária perdida, comumente usados hoje, ainda não reúnem todas as propriedades físicas, químicas e biológicas exigidas e não se comparam aos tecidos do órgão dental sadio. Por isso, a intenção de conseguir um material restaurador ideal é constante entre os pesquisadores.

O amálgama, quando indicado, ainda continua sendo o material escolhido para restauração de dentes posteriores, devido às qualidades mecânicas satisfatórias, como resistências à compressão e ao desgaste ${ }^{1,5}$. De comportamento clínico adequado e previsível, o baixo custo do material e de sua "fácil" manipulação o colocam como de eleição a fim de que possa ser retido na cavidade e protegendo o dente ${ }^{12}$.

Uma melhora do amálgama de composição convencional, foi o aperfeiçoamento das ligas para amálgama com dispersão do eutético de cobre ou de alto conteúdo de cobre (+ de $6 \%$ ) por INNES; YOUDELIS ${ }^{33}$ e depois com $\mathrm{ASGAR}^{4}$ com ligas enriquecidas com cobre de partículas únicas, demonstrando integridade marginal e resistência à corrosão superiores ${ }^{18,33,52}$ e menor "creep" , quando comparados aos de composição convencional.

Em relação a outros materiais restauradores atuais, o amálgama não tem adesão ao dente, portanto devem ser realizadas retenções nas paredes do preparo cavitário, como cauda de andorinha, sulcos ou canaletas para reter o 
material na cavidade. Ao utilizar-se desses artifícios, desgasta-se estruturas dentárias sadias tornando as cavidades mais amplas e extensas que o necessário.

Outro fator que ocorre com as restaurações de amálgama é a microinfiltração na interface dente/restauração, que nos amálgamas com ligas de composição convencional são compensados pela corrosão ${ }^{5}$. Todavia, vários estudos $^{2,12,14,16,19,21,23,29,34,40,44,45,78,79,83,86,87,89,91,93}$ têm mostrado a efetividade da diminuição da microinfiltração e preservação de estrutura dentária sã, quando da aplicação de monômeros adesivos às paredes do preparo cavitário, antes da colocação do amálgama.

Isso pôde ser feito com auxílio da técnica do condicionamento ácido do esmalte preconizada por BUONOCORE ${ }^{11}$, onde não se realiza tanto desgaste e sim, atentando-se principalmente na remoção de todo tecido cariado, deixando desta forma o preparo mais conservador e por conseqüência o dente com maior resistência ${ }^{86,93}$.

Devido a várias correntes de autores contrários aos amálgamas pela contaminação do mercúrio, principalmente europeus e escandinavos, pode-se concordar com ENGLE ${ }^{25}$, verificando ser inferior ao nível do total de exposição estabelecido pelos órgãos reguladores. Um aspecto polêmico enfrentado pelo amálgama é a possível contaminação do profissional, pessoal auxiliar, paciente e ambiente pelo vapor de mercúrio liberado da restauração ou pelo manuseio do metal $\left.\right|^{25,26,56}$. Com a fabricação de novas ligas para restaurações dentais contendo em sua formulação paládio ${ }^{35}$, índio ${ }^{13,18}$ e gálio ${ }^{1,57,75}$, vários trabalhos $8,32,35,36,46,49,51,57,59,61,67,75,80,84,85,98,99,101$ têm sido desenvolvidos com respeito a diversas áreas, sempre com autores sugerindo estudos acurados a 
longo prazo e melhor desenvolvimento do material para posterior liberação para uso clínico.

Estudos de toxicidade têm sido relatados na literatura como $\mathrm{LYON}^{43}$, que fizeram restrição ao uso das ligas gálio-ouro por apresentarem fibrose (corpo estranho) no tecido de ratos quando colocadas subcutaneamente. Já outros autores $^{13,31,47,62,97}$, através de testes apropriados, mostraram a segurança clínica das ligas de gálio obtendo dados para enquadrá-las como substâncias comuns de acordo com as leis farmacêuticas. PSARRAS et al. ${ }^{76}$ não encontraram diferença entre as ligas de gálio e ligas para amálgama, estimulando então novos estudos e desenvolvimentos sobre as novas ligas livres de mercúrio, ao contrário de ROCKWELL et al. ${ }^{77}$ que verificou não haver diferença nos nívieis de citotoxicidade entre as duas ligas de gálio, mas ambas foram sempre mais citotóxicas que Tytin, provavelmente devido à pobre resistência à corrosão das duas ligas de gálio.

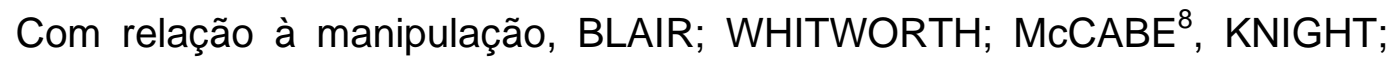
BERRY $^{38}$ e OKAMOTO;HORIBE ${ }^{61}$ constataram que a técnica para restauração com liga de gálio é mais simples e rápida que a de amálgama, indicando inclusive para uso na Odontopediatria, concordando com KAGA ${ }^{36}$. Ao contrário, MASH et al. ${ }^{46}$ observaram dificuldades na colocação e condensação da referida liga na cavidade, o mesmo ocorrendo com LEINFELDER ${ }^{41}$, pois durante a inserção e condensação, a mistura tende a mover-se para cima aderindo em demasia ao instrumento, sugerindo condensadores revestidos de Teflon para diminuir aderência ou colocar etanol ${ }^{28}$ ou menos de $5 \mu$ de álcool ${ }^{51}$ na massa, o que segundo os pesquisadores não alteraram as propriedades das ligas estudadas. 
BERRY; NICHOLSON; TROENDLE ${ }^{6}$, LACY; STANINEC ${ }^{40}$ e SHIMIZU; UI; $\mathrm{KAWAKAMI}^{83}$ associaram um adesivo resinoso ao amálgama possibilitando maior retenção da restauração, preservação de estrutura dental sadia e redução de microinfiltração ${ }^{14,16,21,23,87,89,93}$ nas margens cavitárias, sugerindo então ser uma técnica efetiva, inclusive sem que haja necessidade de confecção de sulcos, canaletas ou cauda de andorinha.

PEGORARO;MONDELLI ${ }^{68}$, PINTO $^{73}$ e SETCOS; STANINEC; WILSON ${ }^{82}$ não notaram diferença estatística significante entre as ligas com ou sem adesivos, mas RUZICKOVA et al. ${ }^{78,79}$, que segundo análise das características das restaurações "adesivas" observaram que apresentaram um desempenho clínico satisfatório, tão bom quanto as restaurações realizadas com amálgama sem adesivos.

Alguns sistemas adesivos utilizados com o objetivo de unir o material restaurador ao preparo cavitário, apresentaram uma consistência tal que, durante a condensação do amálgama na cavidade, incorporaram-se à massa da restauração podendo afetar as propriedades físicas e mecânicas do material, ocorrência observada e bem ilustrada através do microscópio eletrônico de varredura (MEV) por PEGORARO; MONDELLI ${ }^{68}$, PINTO $^{73}$ e SETCOS; STANINEC; WILSON ${ }^{82}$, inclusive podendo causar diminuição da resistência à compressão ${ }^{1}$.

OSBORNE et al. ${ }^{66}$ e ABREU ${ }^{1}$ constataram que o Galloy alcançou melhores resultados que os amálgamas, quanto à resistência diametral, determinando que o sistema restaurador à base de gálio fosse aceitável e adequado, tornando-o viável como uma alternativa ao amálgama dentário, com a ressalva de que haveria de se 
melhorar as características de manipulação do material antes da aceitação difundida para uso clínico ${ }^{8}$.

Em contrapartida estudos clínicos de NAVARRO et al. ${ }^{57}$ e PRAZERES; BALLESTER; SANTOS ${ }^{75}$ com as ligas de gálio Gallium Alloy GF (Tokuriki Honten, Japan) mostraram altas proporções de $\operatorname{corrosão}^{67}$ e sensibilidade pós-operatória, sendo consideradas inaceitáveis ${ }^{63,64,65}$ para uso em pacientes por apresentarem fendas, dentes fraturados e manchas marginais.

OSBORNE ${ }^{63}$ e SARKAR et al. ${ }^{81}$ foram capazes de simular a corrosão induzida nos materiais restauradores contendo gálio, os quais observaram uma expansão excessiva associada com os produtos de corrosão, contribuindo então para a sensibilidade pós-operatória e fratura do dente com o uso deste tipo de material restaurador.

Pelos resultados da presente pesquisa, verificou-se que a liga de gálio, Galloy (SDI) teve valores médios maiores que as outras duas ligas para amálgama, tanto em relação ao teste de perda ou ganho de peso como para o de rugosidade superficial, não apresentando diferença estatística significante quanto ao tipo de adesivo utilizado, e a liga Tytin Plus (S.S.White) alcançou os melhores resultados, com quaisquer dos adesivos, como mostra a figura 10 , representado pelos gráficos nas figuras 11 e 12 .

Estes dados vêm de encontro à afirmativa de NAVARRO et al. ${ }^{57} \mathrm{e}$ outros $^{24,58,63,64,65,67,75,81,94}$ de ter uma correlação positiva entre a resistência à corrosão, sensibilidade pós-operatória e fratura dentária. 


\subsection{DO MÉTODO}

Ao selecionarmos as ligas para o estudo, escolhemos o Dispersalloy (Dentsply) por possuir alto conteúdo de cobre do tipo fase dispersa e por ser um material largamente pesquisado e com melhores resultados comparados com outros materiais restauradores, Tytin Plus (S.S.White) por ser uma liga para amálgama de alto teor de cobre do tipo partícula única, e portanto, sem fase gama-2 e Galloy (SDI) por ter liga de gálio em substituição ao mercúrio.

Para conseguir uma uniformidade, os corpos-de-prova foram confeccionados em ambiente com temperatura controlada, segundo a Especificação $n^{0} 1$ da A.D.A. ${ }^{3}$, controlando também a umidade relativa do ar.

Mesmo que FICHMAN; SILVA; GUIDI ${ }^{26}$ observassem pouca variabilidade nos dosadores de limalha e mercúrio, pesamos os componentes em balança de precisão. O mercúrio, pela facilidade e maior cuidado na manipulação, usamos o dosador da Sybron/Kerr. Para todos os espécimes, no caso do Dispersalloy e Tytin Plus, utilizamos a mesma quantidade de liga, juntamente com a quantidade de mercúrio estabelecida pelo fabricante da respectiva liga, segundo a Especificação $n^{0} 1$ da A.D.A. ${ }^{3}$. Para o Galloy os componentes apresentavam-se pré-dosados, em cápsulas DP (“Direct Placement" = colocação direta).

Pelo trabalho de NASCIMENTO et al. $^{56}$, o qual as cápsulas rosqueáveis reutilizáveis apresentaram valores mais elevados de vazamento de mercúrio, utilizamos dessa forma as cápsulas descartáveis, utilizadas apenas uma vez, de tampa lisa, mostrando uma segurança maior e melhor higiene de trabalho. 
Demos preferência ao amalgamador mecânico motorizado que ao amalgamador manual, segundo a maior facilidade e melhor uniformidade da massa de amálgama $27,52,56,69,96$. O amalgamador Ultramat 2 (SDI) foi usado na pesquisa por ser um aparelho moderno, novo, possuir a redoma de proteção contra escapes de gases ou componentes durante a amalgamação, ter uma forquilha auto-ajustável, no caso de usar-se cápsula de outro fabricante, e por estar a disposição em nosso local de trabalho.

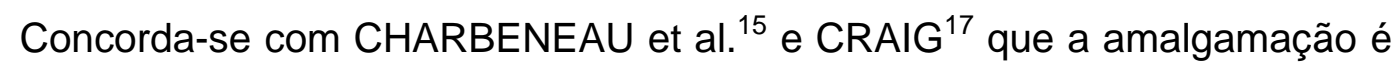
um trabalho, durante o qual existe um consumo de energia, dependendo de três fatores principais (velocidade, tempo e força) e interdependentes. O primeiro e o último, pelo amalgamador ser um aparelho novo, partiu-se do princípio de já estar calibrado e regulado. A escolha do tempo de amalgamação baseou-se no fato de que a liga Galloy, essa do mesmo fabricante do aparelho Ultramat 2, (SDI = Southern Dental Industries), recomendava-se o tempo de 8 segundos.

As duas ligas para amálgama apresentaram perda de mercúrio em quantidades diferentes se subtraírmos do peso liga/mercúrio inicial o peso do corpo-de-prova final variando o valor da massa como pode ser constatado nas tabelas, nos Anexos. Os espécimes foram estocados em estufa a $37{ }^{\circ} \mathrm{C}$, por não haver diferença entre a armazenagem em estufa ou saliva artificial na mesma temperatura, como afirmou PHILLIPS ${ }^{70}$.

Um trabalho desenvolvido por SWARTZ; PHILLIPS; TANNIR ${ }^{88}$, em 1958, utilizando difração por raios $X$ de restaurações a amálgama que encontravam-se manchadas por uso clínico, indicou a existência de um sulfeto como fator predominante na descoloração, tendo sido evidenciados apenas traços de cloretos e outros compostos. PHILLIPS ${ }^{71}$ afirma que os sulfetos, de alguma forma 
presentes na cavidade oral, são os agentes de corrosão química mais comuns. Devemos lembrar que vários alimentos como ovos, cebola e outros contém quantidade significante de enxofre, formando sulfetos diversos como os de hidrogênio e amônia, que possuem predileção por corroer a prata, o cobre e o mercúrio presentes nas ligas de amálgama.

O dispositivo utilizado para realizar o teste de resistência à corrosão é similar ao usado por TUCCCILO;NIELSEN ${ }^{92}$ apresentando algumas modificações feitas no Departamento de Dentística da Faculdade de Odontologia de Bauru da Universidade de São Paulo. Através de um pequeno motor elétrico, ele faz com que as rodas de plástico girem ao redor de um eixo central, movimentando-se lentamente com velocidade angular de 1 rotação por minuto (rpm). Isso permite uma exposição cíclica dos corpos-de-prova ao ar e à solução química à base de sulfeto de sódio a $5 \%$ utilizada na experimentação. Uma vez que 1600 rotações equivalem a 6 meses de uso clínico em meio oral, 24 horas de teste "in vitro" corresponderia aproximadamente a 6 meses de uso clínico ${ }^{92}$. Esse teste pode ser considerado bastante agressivo, pois além da concentração da solução de sulfeto de sódio ser de 5 \% ( a maioria dos trabalhos emprega concentração de 0,5\%), não houve o sistema de auto-limpeza oral realizado com a mastigação, escovação, movimentação da língua e bochecha, que ocorre no caso "in vivo".

DESCHEPPER et al. ${ }^{20}$ usaram duas soluções de Riger, uma deoxigenada e outra normal, e NAKAJIMA; WOLDU; OKABE ${ }^{55}$ examinaram o efeito da solução salina a $0,9 \%$ de $\mathrm{NaCl}$ sobre os materiais testados, sendo que nos dois trabalhos a liga de gálio apresentou uma corrosão eletroquímica acelerada, a qual foi mais propensa à corrosão que a liga para amálgama de alto conteúdo de cobre.

Esta alteração química na superfície das ligas metálicas pode ser evidenciada pela análise da rugosidade de superfície conjuntamente com o teste de perda ou ganho de peso das ligas estudadas. A rugosidade de superfície (apresentada através de um gráfico na figura 13) quando aumentada pela oxidação e corrosão propicia um maior acúmulo de placa na região, principalmente nas áreas de difícil higienização, onde observa-se um maior percentual de falhas destas restaurações. Este acúmulo de placa ocorrendo na 
superfície das ligas poderá predispor as restaurações a sofrerem oxidação e corrosão e o conseqüente comprometimento periodontal.

\subsection{ANÁlise dos RESUltados}

Através do exame das médias de perda de peso das três ligas analisadas, constatou-se pelas figuras 10, 11 e 14 que, na solução de sulfeto de sódio a $5 \%$ utilizada, esta produziu algum tipo de interação com a superfície dos corpos-de-prova, culminando com a perda de peso dos mesmos.

$\mathrm{Na}$ análise estatística, foram relacionados todos os resultados individuais constantes nos Anexos. A Especificação $n^{0} 1$ da A.D.A. ${ }^{3}$ recomenda que sejam feitos cinco corpos-de-prova para cada condição estudada, mas apenas cinco corpos-de-prova para cada situação são em pequeno número para verificarmos a variação dos resultados, devendo ser no mínimo com 10 espécimes para cada condição pesquisada.

Pelo método paramétrico foi feita uma análise de variância (ANOVA) a dois critérios de classificação (liga $\mathrm{x}$ adesivo), englobando todos os resultados, primeiramente para os testes de perda de peso e outra para resistência à corrosão. Foi observado diferença estatística significante entre as ligas e não houve diferença estatística significante entre os sistemas adesivos empregados, mostrando comportamentos diferentes dependendo da combinação desses fatores. A partir daí, utilizamos o teste de Tukey-Kramer para comparações individuais com nível de significância de 5\% ( $p<0,05)$. As figuras 14 e 15 mostram essas comparações: 
Através dos exames das médias de perda de peso das ligas estudadas, podemos constatar algum tipo de interação com a superfície dos corpos de prova, culminando com a perda de peso das ligas para amálgama e liga à base de gálio.

Os resultados obtidos para a variável rugosidade de superfície e a análise estatística se encontram nas figuras 10, 12, 13 e 15. Esses valores representam as médias obtidas de 4 medições realizadas em cada corpo-de-prova das ligas estudadas, cujos dados originais constam em Anexos.

WILLIANS $^{100}$ define manchamento como sendo a produção de um fino filme aderente sobre o metal, interferindo com o brilho original e usualmente causando mudança de cor, podendo aumentar o peso da liga, enquanto a corrosão pode ser definida como a perda de peso de um metal. PHILLIPS ${ }^{71}$ e SWARTZ; PHILLIPS; TANNIR $^{88}$ definem a corrosão como um ataque gradual químico e eletroquímico do metal pela atmosfera, umidade e outros agentes, enquanto o manchamento seria uma descoloração da superfície devido à formação de óxidos. Todos autores concordam ser difícil a distinção clínica entre o manchamento e corrosão, sendo que tais termos vêm com freqüência sendo usados indiferentemente na literatura odontológica. Analisando o comportamento das ligas testadas, podemos verificar que todas apresentaram perda de peso, após imersão em solução de sulfeto de sódio a $5 \%$.

Frente aos resultados obtidos no teste de perda de peso e no teste de rugosidade de superfície, as ligas para amálgama Dispersalloy e Tytin Plus tiveram um comportamento bastante similar, demonstrando melhor homogeneidade e resistência à oxidação ao meio corrosivo a que foram submetidas. O mesmo não aconteceu com a liga Galloy, apresentando um comportamento adverso às demais ligas, levando-nos a pensar nos resultados obtidos pelos autores NAVARRO et al. ${ }^{57}$ e OSBORNE; SUMMITT ${ }^{64,65}$, os quais contra-indicam a utilização clínica da liga à base de gálio, em decorrência da elevada susceptibilidade desta em sofrer oxidação e corrosão. 


\section{6 - CONCLUSÕES}

Notou-se que todos os corpos-de-prova, em todas as situações examinadas, perderam peso e tiveram aumento dos níveis de rugosidade de superfície, após a imersão por 24 horas na solução de sulfeto de sódio a 5 \%.

Pelos resultados obtidos, houve diferença estatisticamente significante entre as três ligas, mas não entre os sistemas adesivos empregados.

A liga à base de gálio Galloy (sem ou com adesivo) apresentou os piores resultados, comparados aos dos amálgamas, tanto no teste de perda de peso como no de rugosidade superficial, exceção observada para o Galloy, com o PAAMA-2, referente à rugosidade; a liga Tytin Plus, sem ou com quaisquer dos adesivos, alcançou os melhores resultados nos dois testes executados, a não ser com o Tytin Plus sem adesivo. 
ANEXOS

Colocamos nesta parte os resultados originais de todos os espécimes confeccionados.

Na parte superior mostra o material que fora utilizado, sem ou com adesivo, com sua respectiva letra entre parênteses. A primeira coluna revela a liga para amálgama ou de gálio, sem ou com adesivo e o número do corpo-de-prova, num total de 10 para cada situação estudada. As três colunas seguintes (peso, rugosidade e rugosidade média) referem-se aos resultados dos corpos-de-prova confeccionados imediatamente, enquanto que as últimas três mostram os valores obtidos após a colocação deles numa solução de sulfeto de sódio a $5 \%$ por um período de 24 horas. A última linha demosntra a média dos pesos e rugosidades médias inicialmente e após 24 horas, para visualização e comparação entre os exemplares. 
Dispersalloy (D)

\begin{tabular}{|c|c|c|c|c|c|c|}
\hline $\begin{array}{l}\text { Ligal } \\
\text { cdp }\end{array}$ & $\begin{array}{l}\text { peso } \\
(\mathrm{g})\end{array}$ & $\begin{array}{c}\text { rugosidade } \\
(\mu \mathrm{m})\end{array}$ & $\begin{array}{c}\text { rugosidade } \\
\text { média }\end{array}$ & $\begin{array}{l}\text { peso } \\
(\mathrm{g})\end{array}$ & $\begin{array}{c}\text { rugosidade } \\
(\mu \mathrm{m})\end{array}$ & $\begin{array}{l}\text { rugosidade } \\
\text { média }\end{array}$ \\
\hline \multirow[t]{2}{*}{ D01 } & 2,4065 & $\begin{array}{l}0,278 \\
0,404 \\
0,332\end{array}$ & \multirow[t]{2}{*}{0,331} & 2,4012 & $\begin{array}{l}1,740 \\
1,610 \\
1,980\end{array}$ & 1,780 \\
\hline & & $\begin{array}{l}0,311 \\
0,223\end{array}$ & & & $\begin{array}{l}1,790 \\
1,600\end{array}$ & \multirow{4}{*}{1,513} \\
\hline \multirow[t]{3}{*}{ D02 } & 2,4701 & 0,258 & \multirow[t]{3}{*}{0,260} & \multirow[t]{3}{*}{2,4653} & 1,430 & \\
\hline & & 0,294 & & & 1,160 & \\
\hline & & $\begin{array}{l}0,266 \\
0,388\end{array}$ & & & $\begin{array}{l}1,860 \\
1670\end{array}$ & \\
\hline \multirow[t]{4}{*}{ D03 } & 2,5200 & 0,201 & \multirow[t]{4}{*}{0,290} & \multirow[t]{4}{*}{2,5149} & 1,570 & \multirow[t]{2}{*}{1,618} \\
\hline & & 0,244 & & & 1,700 & \\
\hline & & 0,327 & & & 1,530 & \\
\hline & & 0,392 & & & 1,260 & \multirow{4}{*}{1,328} \\
\hline \multirow[t]{4}{*}{ D04 } & 2,4399 & 0,440 & \multirow[t]{4}{*}{0,497} & \multirow[t]{4}{*}{2,4343} & 1,180 & \\
\hline & & 0,269 & & & 1,550 & \\
\hline & & 0,887 & & & 1,320 & \\
\hline & & 0,366 & & & 1,690 & \multirow{5}{*}{2,050} \\
\hline \multirow[t]{4}{*}{ D05 } & 2,6186 & 0,564 & \multirow[t]{4}{*}{0,446} & \multirow[t]{4}{*}{2,6103} & 2,120 & \\
\hline & & 0,471 & & & 2,500 & \\
\hline & & 0,383 & & & 1,890 & \\
\hline & & 0,381 & & & 0,634 & \\
\hline \multirow[t]{4}{*}{ D06 } & 2,8793 & 0,398 & \multirow[t]{4}{*}{0,414} & \multirow[t]{4}{*}{2,8711} & 0,556 & \multirow[t]{4}{*}{0,667} \\
\hline & & 0,412 & & & 0,697 & \\
\hline & & 0,477 & & & 0,781 & \\
\hline & & 0,822 & & & 1,450 & \\
\hline \multirow[t]{4}{*}{ D07 } & 2,7618 & 0,715 & \multirow[t]{4}{*}{0,599} & \multirow[t]{4}{*}{2,7553} & 1,140 & 1,383 \\
\hline & & 0,374 & & & 1,380 & \\
\hline & & 0,487 & & & 1,560 & \\
\hline & & 0,712 & & & 1,170 & \\
\hline D08 & 2,6433 & 0,482 & 0,639 & 2,6362 & 1,410 & 1,265 \\
\hline & & 0,677 & & & 1,250 & \\
\hline & & 0,685 & & & 1,230 & \\
\hline & & 0,880 & & & 1,040 & \\
\hline D09 & 2,8800 & 0,821 & 0,762 & 2,8728 & 1,460 & 1,380 \\
\hline & & 0,633 & & & 1,900 & \\
\hline & & 0,711 & & & 1,120 & \\
\hline & & 0,813 & & & 1,460 & \\
\hline D10 & 2,7691 & 0,427 & 0,861 & 2,7610 & 1,270 & 1,993 \\
\hline & & 1,230 & & & 3,840 & \\
\hline & & 0,977 & & & 1,400 & \\
\hline $\mathbf{M}$ & 2,6389 & - & 0,510 & 2,6322 & - & 1,498 \\
\hline
\end{tabular}


$\mathbf{M}=$ Média

Galloy (G)

\begin{tabular}{|c|c|c|c|c|c|c|}
\hline $\begin{array}{c}\text { Ligal } \\
\text { cdp }\end{array}$ & $\begin{array}{l}\text { idade }=1 \mathrm{~h} \\
\text { peso }(\mathrm{g})\end{array}$ & $\begin{array}{c}\text { rugosidade } \\
(\mathrm{Ra}=\mu \mathrm{m})\end{array}$ & $\begin{array}{c}\text { médias } \\
(\mathrm{Ra}=\mu \mathrm{m})\end{array}$ & $\begin{array}{c}\text { idade }=24 \mathrm{~h} \\
\text { peso }(\mathrm{g})\end{array}$ & $\begin{array}{c}\text { rugosidade } \\
(\mathrm{Ra}=\mu \mathrm{m})\end{array}$ & $\begin{array}{l}\text { médias } \\
(\mathrm{Ra}=\mu \mathrm{m})\end{array}$ \\
\hline \multirow{5}{*}{ G01 } & \multirow{5}{*}{1,6930} & 0,776 & \multirow{5}{*}{0,853} & \multirow{3}{*}{1,6707} & 2,880 & \multirow{3}{*}{2,020} \\
\hline & & 0,982 & & & 1,810 & \\
\hline & & 0,765 & & & 1,440 & \\
\hline & & 0,890 & & & 1,950 & \\
\hline & & 1,120 & & \multirow{5}{*}{1,7200} & 2,350 & \multirow{5}{*}{2,513} \\
\hline \multirow[t]{4}{*}{ G02 } & 1,7402 & 0,877 & \multirow[t]{4}{*}{1,003} & & 2,410 & \\
\hline & & 1,083 & & & 1,660 & \\
\hline & & 0,930 & & & 3,630 & \\
\hline & & 0,372 & & & 1,200 & \\
\hline \multirow[t]{4}{*}{ G03 } & 1,5955 & 0,199 & \multirow[t]{4}{*}{0,397} & \multirow[t]{4}{*}{1,5763} & 0,797 & \multirow[t]{4}{*}{1,005} \\
\hline & & 0,561 & & & 0,873 & \\
\hline & & 0,454 & & & 1,150 & \\
\hline & & 1,260 & & & 6,130 & \\
\hline \multirow[t]{4}{*}{ G04 } & 1,8056 & 1,371 & \multirow[t]{4}{*}{1,238} & \multirow[t]{4}{*}{1,7857} & 5,160 & \multirow[t]{4}{*}{4,223} \\
\hline & & 1,255 & & & 2,980 & \\
\hline & & 1,064 & & & 2,620 & \\
\hline & & 0,940 & & & 1,420 & \\
\hline \multirow[t]{4}{*}{ G05 } & 1,8865 & 0,323 & \multirow[t]{4}{*}{0,495} & \multirow[t]{4}{*}{1,8631} & 0,586 & \multirow[t]{4}{*}{0,971} \\
\hline & & 0,404 & & & 0,792 & \\
\hline & & 0,312 & & & 0,687 & \\
\hline & & 0,257 & & & 2,230 & \\
\hline \multirow[t]{4}{*}{ G06 } & 1,8620 & 0,121 & \multirow[t]{4}{*}{0,185} & \multirow[t]{4}{*}{1,8370} & 2,750 & \multirow[t]{4}{*}{2,618} \\
\hline & & 0,146 & & & 2,850 & \\
\hline & & 0,215 & & & 2,640 & \\
\hline & & 0,571 & & & 1,210 & \\
\hline G07 & 1,8825 & 0,465 & 0,570 & 1,8625 & 1,410 & 1,310 \\
\hline & & 0,582 & & & 1,230 & \\
\hline & & 0,663 & & & 1,390 & \\
\hline & & 1,088 & & & 2,500 & \\
\hline G08 & 1,8189 & 0,732 & 0,939 & 1,800 & 1,460 & 1,990 \\
\hline & & 1,112 & & & 2,190 & \\
\hline & & 0,821 & & & 1,810 & \\
\hline & & 0,448 & & & 3,050 & \\
\hline G09 & 1,8918 & 0,561 & 0,623 & 1,8706 & 1,180 & 1,893 \\
\hline & & 0,650 & & & 1,320 & \\
\hline & & 0,832 & & & 2,020 & \\
\hline & & 0,647 & & & 1,160 & \\
\hline G10 & 1,8016 & 0,850 & 0,875 & 1,7791 & 1,460 & 1,538 \\
\hline & & 0,794 & & & 1,470 & \\
\hline & & 1,210 & & & 2,060 & \\
\hline
\end{tabular}




\begin{tabular}{|l|l|l|l|l|l|l|}
$\mathbf{M}$ & 1,7978 & - & 0,718 & 1,7765 & - & 2,008 \\
\hline
\end{tabular}

$\mathbf{M}=$ Média

Tytin Plus (T)

\begin{tabular}{|c|c|c|c|c|c|c|}
\hline $\begin{array}{l}\text { Ligal } \\
\text { cdp }\end{array}$ & $\begin{array}{c}\text { idade }=1 \mathrm{~h} \\
\text { peso }(\mathrm{g})\end{array}$ & $\begin{array}{c}\text { rugosidade } \\
(\mathrm{Ra}=\mu \mathrm{m})\end{array}$ & $\begin{array}{c}\text { médias } \\
(\mathrm{Ra}=\mu \mathrm{m})\end{array}$ & $\begin{array}{c}\text { idade }=24 \mathrm{~h} \\
\text { peso }(\mathrm{g})\end{array}$ & $\begin{array}{c}\text { rugosidade } \\
(\mathrm{Ra}=\mu \mathrm{m})\end{array}$ & $\begin{array}{c}\text { médias } \\
(\mathrm{Ra}=\mu \mathrm{m})\end{array}$ \\
\hline \multirow[t]{4}{*}{ T01 } & \multirow[t]{4}{*}{ 2,3915 } & $\begin{array}{l}0,807 \\
0,297\end{array}$ & \multirow[t]{4}{*}{0,625} & \multirow[t]{3}{*}{2,3852} & $\begin{array}{l}1,430 \\
1,690\end{array}$ & \multirow[t]{4}{*}{1,688} \\
\hline & & 0,532 & & & 1,950 & \\
\hline & & 0,862 & & & 1,680 & \\
\hline & & 0,510 & & \multirow{5}{*}{2,5025} & 1,340 & \\
\hline \multirow[t]{4}{*}{ T02 } & 2,5140 & 0,519 & \multirow[t]{4}{*}{0,705} & & 1,117 & \multirow[t]{3}{*}{1,247} \\
\hline & & 0,918 & & & 1,530 & \\
\hline & & 0,874 & & & 1,000 & \\
\hline & & 0,285 & & & 0,394 & \\
\hline \multirow[t]{4}{*}{ T03 } & 2,5804 & 0,290 & \multirow[t]{4}{*}{0,296} & \multirow[t]{4}{*}{2,5696} & 0,385 & \multirow[t]{4}{*}{1,056} \\
\hline & & 0,287 & & & 2,880 & \\
\hline & & 0,323 & & & 0,566 & \\
\hline & & 0,389 & & & 0,580 & \\
\hline \multirow[t]{4}{*}{ T04 } & 2,6936 & 0,391 & \multirow[t]{4}{*}{0,407} & \multirow[t]{4}{*}{2,6824} & 0,781 & \multirow[t]{4}{*}{0,724} \\
\hline & & 0,437 & & & 0,771 & \\
\hline & & 0,412 & & & 0,762 & \\
\hline & & 0,293 & & & 0,656 & \\
\hline \multirow[t]{4}{*}{ T05 } & 2,6800 & 0,444 & \multirow[t]{4}{*}{0,339} & \multirow[t]{4}{*}{2,6693} & 0,821 & \multirow[t]{4}{*}{0,678} \\
\hline & & 0,279 & & & 0,365 & \\
\hline & & 0,338 & & & 0,875 & \\
\hline & & 0,665 & & & 1,670 & \\
\hline \multirow[t]{4}{*}{ T06 } & 2,8253 & 0,573 & \multirow[t]{4}{*}{0,625} & \multirow[t]{4}{*}{2,8126} & 0,879 & \multirow[t]{4}{*}{1,162} \\
\hline & & 0,622 & & & 1,115 & \\
\hline & & 0,641 & & & 0,983 & \\
\hline & & 0,280 & & & 1,290 & \\
\hline \multirow[t]{4}{*}{ T07 } & 2,8600 & 0,372 & \multirow[t]{4}{*}{0,406} & 2,8502 & 3,060 & 1,793 \\
\hline & & 0,293 & & & 1,350 & \\
\hline & & 0,677 & & & 1,470 & \\
\hline & & 0,441 & & & 1,270 & \\
\hline T08 & 2,8535 & 0,569 & 0,452 & 2,8495 & 1,570 & 1,498 \\
\hline & & 0,420 & & & 1,660 & \\
\hline & & 0,378 & & & 1,490 & \\
\hline & & 0,788 & & & 1,840 & \\
\hline T09 & 2,9266 & 0,833 & 0,836 & 2,9185 & 1,150 & 1,488 \\
\hline & & 0,784 & & & 1,340 & \\
\hline & & 0,937 & & & 1,620 & \\
\hline & & 0,355 & & & 1,291 & \\
\hline T10 & 2,7957 & 0,461 & 0,424 & 2,7840 & 1,100 & 1,245 \\
\hline
\end{tabular}




\begin{tabular}{|l|l|c|l|l|l|l|} 
& & 0,516 & & & 1,260 & \\
$\mathbf{M}$ & $\mathbf{2 , 7 1 2 1}$ & 0,363 & & & 1,330 & \\
\end{tabular}

$\mathbf{M}=$ Média

Tytin Plus com adesivo All-Bond 2 (TA)

\begin{tabular}{|c|c|c|c|c|c|c|}
\hline $\begin{array}{c}\text { Ligal } \\
\text { cdp }\end{array}$ & $\begin{array}{l}\text { idade }=1 \mathrm{~h} \\
\text { peso }(\mathrm{g})\end{array}$ & $\begin{array}{l}\text { rugosidade } \\
\text { inicial }(\mu \mathrm{m})\end{array}$ & $\begin{array}{c}\text { médias } \\
(\mathrm{Ra}=\mu \mathrm{m})\end{array}$ & $\begin{array}{c}\text { idade }=24 \mathrm{~h} \\
\text { peso }(\mathrm{g})\end{array}$ & $\begin{array}{c}\text { rugosidade } \\
\text { final }(\mu \mathrm{m})\end{array}$ & $\begin{array}{l}\text { médias } \\
(\mathrm{Ra}=\mu \mathrm{m})\end{array}$ \\
\hline \multirow{5}{*}{ TA01 } & \multirow{5}{*}{2,4172} & 0,535 & \multirow{5}{*}{0,782} & \multirow{3}{*}{2,4158} & 0,625 & \multirow{3}{*}{0,898} \\
\hline & & 0,373 & & & 0,408 & \\
\hline & & 1,050 & & & 1,260 & \\
\hline & & 1,170 & & & 1,300 & \\
\hline & & 0,745 & & \multirow{3}{*}{2,6179} & 0,723 & \multirow{3}{*}{0,840} \\
\hline \multirow[t]{4}{*}{ TA02 } & 2,6197 & 0,685 & \multirow[t]{4}{*}{0,697} & & 0,780 & \\
\hline & & 0,779 & & & 0,877 & \\
\hline & & 0,578 & & & 0,980 & \\
\hline & & 0,374 & & \multirow{3}{*}{2,6236} & 0,642 & \multirow{3}{*}{0,753} \\
\hline \multirow[t]{4}{*}{ TA03 } & 2,6256 & 0,176 & \multirow[t]{4}{*}{0,376} & & 0,812 & \\
\hline & & 0,563 & & & 0,904 & \\
\hline & & 0,389 & & & 0,654 & \\
\hline & & 0,686 & & \multirow{3}{*}{2,7457} & 0,605 & \multirow{3}{*}{1,064} \\
\hline \multirow[t]{4}{*}{ TA04 } & 2,7499 & 0,391 & \multirow[t]{4}{*}{0,497} & & 1,170 & \\
\hline & & 0,392 & & & 0,992 & \\
\hline & & 0,519 & & & 1,490 & \\
\hline & & 0,576 & & \multirow{3}{*}{2,7876} & 0,848 & \multirow{3}{*}{0,858} \\
\hline \multirow[t]{4}{*}{ TA05 } & 2,7907 & 0,598 & \multirow[t]{4}{*}{0,486} & & 0,891 & \\
\hline & & 0,429 & & & 0,868 & \\
\hline & & 0,341 & & & 0,823 & \\
\hline & & 0,517 & & \multirow{3}{*}{2,5907} & 2,190 & \multirow{3}{*}{1,071} \\
\hline \multirow[t]{4}{*}{ TA06 } & 2,5947 & 0,567 & \multirow[t]{4}{*}{0,628} & & 0,481 & \\
\hline & & 0,532 & & & 1,090 & \\
\hline & & 0,897 & & & 0,521 & \\
\hline & & 0,366 & & & 0,597 & \\
\hline \multirow[t]{4}{*}{ TA07 } & 2,5570 & 0,612 & \multirow[t]{4}{*}{0,532} & 2,5526 & 0,722 & 0,665 \\
\hline & & 0,472 & & & 0,556 & \\
\hline & & 0,677 & & & 0,784 & \\
\hline & & 0,657 & & & 1,390 & \\
\hline TA08 & 2,5774 & 1,340 & 1,000 & 2,5741 & 1,050 & 1,225 \\
\hline & & 0,993 & & & 1,210 & \\
\hline & & 1,010 & & & 1,250 & \\
\hline & & 0,879 & & & 1,780 & \\
\hline TA09 & 2,4784 & 0,787 & 0,802 & 2,4737 & 1,290 & 1,370 \\
\hline & & 0,886 & & & 1,060 & \\
\hline & & 0,654 & & & 1,350 & \\
\hline
\end{tabular}




\begin{tabular}{|c|c|c|c|c|c|c|}
\hline TA10 & 2,6501 & $\begin{array}{l}0,647 \\
0,556 \\
0,785 \\
0,575\end{array}$ & 0,641 & 2,6445 & $\begin{array}{l}0,904 \\
0,621 \\
0,561 \\
0,681\end{array}$ & 0,692 \\
\hline M & 2,6061 & - & 0,644 & 2,6026 & - & 0,944 \\
\hline
\end{tabular}

$\mathbf{M}=$ Média

Galloy com adesivo All-Bond 2 (GA)

\begin{tabular}{|c|c|c|c|c|c|c|}
\hline $\begin{array}{l}\text { Ligal } \\
\text { cdp }\end{array}$ & $\begin{array}{l}\text { idade }=1 \mathrm{~h} \\
\text { peso }(\mathrm{g})\end{array}$ & $\begin{array}{l}\text { rugosidade } \\
\text { inicial }(\mu \mathrm{m})\end{array}$ & $\begin{array}{l}\text { médias } \\
(\mathrm{Ra}=\mu \mathrm{m})\end{array}$ & $\begin{array}{c}\text { idade }=24 \mathrm{~h} \\
\text { peso }(\mathrm{g})\end{array}$ & $\begin{array}{c}\text { rugosidade } \\
\text { final }(\mu \mathrm{m})\end{array}$ & $\begin{array}{c}\text { médias } \\
(\mathrm{Ra}=\mu \mathrm{m})\end{array}$ \\
\hline \multirow{5}{*}{ GA01 } & & 2,100 & & & 1,830 & \\
\hline & 1,7114 & 0,446 & 0,970 & 1,6931 & 1,100 & 1,423 \\
\hline & & 0,757 & & & 1,400 & \\
\hline & & 0,578 & & & 1,360 & \\
\hline & & 0,558 & & & 2,120 & \\
\hline \multirow[t]{4}{*}{ GA02 } & 1,7417 & 0,622 & 0,518 & 1,7241 & 2,130 & 2,333 \\
\hline & & 0,554 & & & 2,270 & \\
\hline & & 0,339 & & & 2,810 & \\
\hline & & 0,250 & & & 2,480 & \\
\hline \multirow[t]{4}{*}{ GA03 } & 1,7068 & 0,685 & 0,437 & 1,6897 & 1,810 & 2,520 \\
\hline & & 0,311 & & & 3,830 & \\
\hline & & 0,500 & & & 1,960 & \\
\hline & & 0,353 & & & 0,827 & \\
\hline \multirow[t]{4}{*}{ GA04 } & 1,7585 & 0,299 & 0,521 & 1,7414 & 1,340 & 1,057 \\
\hline & & 1,000 & & & 1,210 & \\
\hline & & 0,432 & & & 0,852 & \\
\hline & & 1,350 & & & 1,890 & \\
\hline \multirow[t]{4}{*}{ GA05 } & 1,8000 & 0,723 & 1,140 & 1,7821 & 1,550 & 1,434 \\
\hline & & 1,710 & & & 1,390 & \\
\hline & & 0,778 & & & 0,906 & \\
\hline & & 0,269 & & & 1,950 & \\
\hline \multirow[t]{4}{*}{ GA06 } & 1,7132 & 0,975 & 0,839 & 1,6958 & 2,140 & 1,960 \\
\hline & & 0,813 & & & 2,040 & \\
\hline & & 1,300 & & & 1,710 & \\
\hline & & 1,430 & & & 1,230 & \\
\hline \multirow[t]{4}{*}{ GA07 } & 1,8141 & 0,957 & 1,187 & 1,7940 & 2,920 & 1,900 \\
\hline & & 1,220 & & & 2,120 & \\
\hline & & 1,140 & & & 1,330 & \\
\hline & & 1,340 & & & 3,040 & \\
\hline \multirow[t]{4}{*}{ GA08 } & 1,8408 & 0,626 & 0,788 & 1,8219 & 1,990 & 2,095 \\
\hline & & 0,508 & & & 1,860 & \\
\hline & & 0,679 & & & 1,490 & \\
\hline & & 0,384 & & & 0,539 & \\
\hline GA09 & 1,7552 & 0,607 & 0,510 & 1,7354 & 1,230 & 1,145 \\
\hline
\end{tabular}




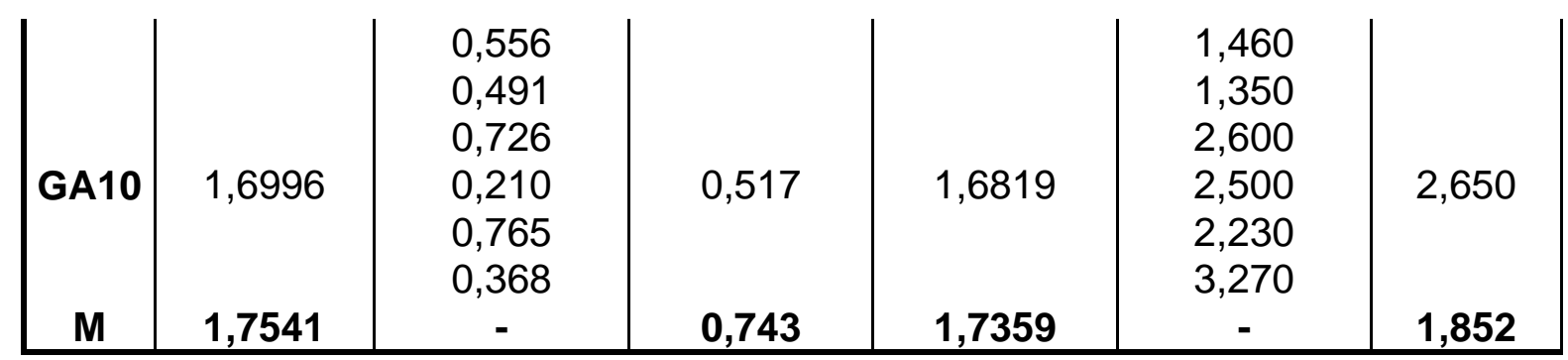

M= Média

Tytin Plus com adesivo PAAMA-2 (TP)

\begin{tabular}{|c|c|c|c|c|c|c|}
\hline $\begin{array}{l}\text { Ligal } \\
\text { cdp }\end{array}$ & $\begin{array}{c}\text { idade }=1 \mathrm{~h} \\
\text { peso }(\mathrm{g})\end{array}$ & $\begin{array}{l}\text { rugosidade } \\
\text { inicial }(\mu \mathrm{m})\end{array}$ & $\begin{array}{c}\text { médias } \\
(\mathrm{Ra}=\mu \mathrm{m})\end{array}$ & $\begin{array}{c}\text { idade }=24 \mathrm{~h} \\
\text { peso }(\mathrm{g})\end{array}$ & $\begin{array}{l}\text { rugosidade } \\
\text { final }(\mu \mathrm{m})\end{array}$ & $\begin{array}{l}\text { médias } \\
(\mathrm{Ra}=\mu \mathrm{m})\end{array}$ \\
\hline \multirow{5}{*}{ TP01 } & & 0,452 & & & 0,420 & \\
\hline & 2,2798 & 0,548 & 0,361 & 2,2790 & 0,400 & 0,440 \\
\hline & & 0,196 & & & 0,520 & \\
\hline & & 0,249 & & & 0,420 & \\
\hline & & 1,420 & & & 1,100 & \\
\hline \multirow[t]{4}{*}{ TP02 } & 2,3425 & 1,510 & 1,505 & 2,3400 & 0,720 & 1,885 \\
\hline & & 1,700 & & & 2,980 & \\
\hline & & 1,390 & & & 2,740 & \\
\hline & & 0,279 & & & 0,580 & \\
\hline \multirow[t]{4}{*}{ TP03 } & 2,3389 & 0,330 & 0,422 & 2,3383 & 0,720 & 0,685 \\
\hline & & 0,272 & & & 0,760 & \\
\hline & & 0,808 & & & 0,680 & \\
\hline & & 0,920 & & & 2,840 & \\
\hline \multirow[t]{4}{*}{ TP04 } & 2,4987 & 0,940 & 0,905 & 2,4959 & 3,330 & 3,075 \\
\hline & & 0,840 & & & 3,840 & \\
\hline & & 0,920 & & & 2,290 & \\
\hline & & 0,968 & & & 1,200 & \\
\hline \multirow[t]{4}{*}{ TP05 } & 2,4833 & 0,881 & 0,806 & 2,4818 & 1,350 & 1,210 \\
\hline & & 0,706 & & & 1,170 & \\
\hline & & 0,667 & & & 1,120 & \\
\hline & & 0,634 & & & 0,840 & \\
\hline \multirow[t]{4}{*}{ TP06 } & 2,5122 & 0,456 & 0,526 & 2,5100 & 1,080 & 0,968 \\
\hline & & 0,523 & & & 1,070 & \\
\hline & & 0,492 & & & 0,880 & \\
\hline & & 0,348 & & & 0,800 & \\
\hline \multirow[t]{4}{*}{ TP07 } & 2,5886 & 0,607 & 0,416 & 2,5877 & 1,400 & 0,775 \\
\hline & & 0,363 & & & 0,480 & \\
\hline & & 0,346 & & & 0,420 & \\
\hline & & 1,420 & & & 2,200 & \\
\hline \multirow[t]{3}{*}{ TP08 } & 2,5869 & 2,220 & 1,454 & 2,5800 & 2,540 & 2,303 \\
\hline & & 1,620 & & & 2,340 & \\
\hline & & 0,557 & & & 2,130 & \\
\hline
\end{tabular}




\begin{tabular}{|c|c|c|c|c|c|c|}
\hline \multirow{3}{*}{ TP09 } & \multirow{2}{*}{2,6784} & 0,874 & 0,839 & 2,6774 & 1,220 & \multirow{2}{*}{1,595} \\
\hline & & $\begin{array}{l}0,034 \\
0,812\end{array}$ & 0,039 & $2,01 / 4$ & $\begin{array}{l}2,000 \\
1,650\end{array}$ & \\
\hline & & 0,835 & & & 1,430 & \\
\hline & & 0,975 & & & 0,600 & \\
\hline TP10 & 2,7666 & 0,572 & 0,681 & 2,7573 & 0,980 & 0,878 \\
\hline & & 0,739 & & & 1,160 & \\
\hline & & 0,437 & & & 0,770 & \\
\hline M & 2,5076 & - & 0,792 & 2,5047 & - & 1,381 \\
\hline
\end{tabular}

$\mathbf{M}=$ Média

Galloy com adesivo PAAMA-2 (GP)

\begin{tabular}{|c|c|c|c|c|c|c|}
\hline $\begin{array}{l}\text { Ligal } \\
\text { cdp }\end{array}$ & $\begin{array}{l}\text { idade }=1 \mathrm{~h} \\
\text { peso }(\mathrm{g})\end{array}$ & $\begin{array}{l}\text { rugosidade } \\
\text { inicial ( } \mu \mathrm{m})\end{array}$ & $\begin{array}{l}\text { médias } \\
(\mathrm{Ra}=\mu \mathrm{m})\end{array}$ & $\begin{array}{c}\text { idade }=24 \mathrm{~h} \\
\text { peso }(\mathrm{g})\end{array}$ & $\begin{array}{l}\text { rugosidade } \\
\text { final }(\mu \mathrm{m})\end{array}$ & $\begin{array}{l}\text { médias } \\
(\mathrm{Ra}=\mu \mathrm{m})\end{array}$ \\
\hline \multirow{5}{*}{ GP01 } & & 0,459 & & & 1,300 & \\
\hline & 1,6910 & 0,495 & 0,705 & 1,6776 & 1,120 & 1,070 \\
\hline & & 1,280 & & & 0,300 & \\
\hline & & 0,584 & & & 1,560 & \\
\hline & & 0,480 & & & 1,500 & \\
\hline \multirow[t]{4}{*}{ GP02 } & 1,6863 & 0,607 & 0,444 & 1,6731 & 1,620 & 1,758 \\
\hline & & 0,191 & & & 2,050 & \\
\hline & & 0,499 & & & 1,860 & \\
\hline & & 1,000 & & & 1,700 & \\
\hline \multirow[t]{4}{*}{ GP03 } & 1,7339 & 1,300 & 0,980 & 1,7200 & 1,860 & 2,540 \\
\hline & & 0,823 & & & 3,140 & \\
\hline & & 0,796 & & & 3,460 & \\
\hline & & 1,700 & & & 2,260 & \\
\hline \multirow[t]{4}{*}{ GP04 } & 1,7030 & 4,730 & 2,870 & 1,6900 & 4,140 & 3,380 \\
\hline & & 3,740 & & & 3,200 & \\
\hline & & 1,310 & & & 3,920 & \\
\hline & & 1,130 & & & 2,800 & \\
\hline \multirow[t]{4}{*}{ GP05 } & 1,6206 & 2,150 & 1,443 & 1,6028 & 2,820 & 2,180 \\
\hline & & 1,260 & & & 1,200 & \\
\hline & & 1,230 & & & 1,900 & \\
\hline & & 0,990 & & & 1,280 & \\
\hline \multirow[t]{4}{*}{ GP06 } & 1,5751 & 1,100 & 1,340 & 1,5600 & 1,460 & 1,510 \\
\hline & & 2,130 & & & 1,800 & \\
\hline & & 1,140 & & & 1,500 & \\
\hline & & 0,853 & & & 2,220 & \\
\hline \multirow[t]{4}{*}{ GP07 } & 1,7487 & 1,250 & 1,118 & 1,7281 & 2,240 & 1,810 \\
\hline & & 1,240 & & & 1,580 & \\
\hline & & 1,130 & & & 1,200 & \\
\hline & & 0,612 & & & 1,360 & \\
\hline GP08 & 1,8171 & 0,300 & 0,823 & 1,8049 & 2,020 & 1,615 \\
\hline
\end{tabular}




\begin{tabular}{|c|c|c|c|c|c|c|}
\hline \multirow{5}{*}{ GP09 } & \multirow{4}{*}{1,7560} & $\begin{array}{l}1,500 \\
0\end{array}$ & \multirow{3}{*}{0,459} & \multirow{3}{*}{1,7425} & 1,620 & \multirow{4}{*}{1,570} \\
\hline & & 0,010 & & & $\perp, 460$ & \\
\hline & & $\begin{array}{l}0,430 \\
0,657\end{array}$ & & & $\begin{array}{l}1,460 \\
1,360\end{array}$ & \\
\hline & & 0,230 & & & 1,760 & \\
\hline & & 0,511 & & & 1,700 & \\
\hline \multirow{4}{*}{ GP10 } & & 1,960 & & & 2,710 & \\
\hline & 1,7120 & 2,240 & 1,978 & 1,6949 & 2,830 & 2,393 \\
\hline & & 1,810 & & & 1,970 & \\
\hline & & 1,900 & & & 2,060 & \\
\hline $\mathbf{M}$ & 1,7048 & - & 1,216 & 1,6894 & - & 1,983 \\
\hline
\end{tabular}

M= Média

Dispersalloy com adesivo All-Bond 2 (DA)

\begin{tabular}{|c|c|c|c|c|c|c|}
\hline $\begin{array}{l}\text { Ligal } \\
\text { cdp }\end{array}$ & $\begin{array}{l}\text { idade }=1 \mathrm{~h} \\
\text { peso }(\mathrm{g})\end{array}$ & $\begin{array}{l}\text { rugosidade } \\
\text { inicial }(\mu \mathrm{m})\end{array}$ & $\begin{array}{l}\text { médias } \\
(\mathrm{Ra}=\mu \mathrm{m})\end{array}$ & $\begin{array}{c}\text { idade }=24 \mathrm{~h} \\
\text { peso }(\mathrm{g})\end{array}$ & $\begin{array}{c}\text { rugosidade } \\
\text { final }(\mu \mathrm{m})\end{array}$ & $\begin{array}{c}\text { médias } \\
(\mathrm{Ra}=\mu \mathrm{m})\end{array}$ \\
\hline \multirow{5}{*}{ DA01 } & & 0,203 & & & 1,220 & \\
\hline & 2,3993 & 0,306 & 0,330 & 2,3934 & 0,907 & 1,084 \\
\hline & & 0,156 & & & 1,100 & \\
\hline & & 0,656 & & & 1,110 & \\
\hline & & 0,534 & & & 1,290 & \\
\hline \multirow[t]{4}{*}{ DA02 } & 2,3925 & 0,530 & 0,553 & 2,3862 & 1,410 & 1,340 \\
\hline & & 0,526 & & & 1,480 & \\
\hline & & 0,623 & & & 1,180 & \\
\hline & & 0,251 & & & 0,841 & \\
\hline \multirow[t]{4}{*}{ DA03 } & 2,4289 & 0,305 & 0,273 & 2,4225 & 0,741 & 0,795 \\
\hline & & 0,240 & & & 0,808 & \\
\hline & & 0,295 & & & 0,791 & \\
\hline & & 0,115 & & & 1,060 & \\
\hline \multirow[t]{4}{*}{ DA04 } & 2,6092 & 0,169 & 0,252 & 2,6014 & 1,010 & 1,034 \\
\hline & & 0,291 & & & 0,915 & \\
\hline & & 0,433 & & & 1,150 & \\
\hline & & 0,245 & & & 1,060 & \\
\hline \multirow[t]{4}{*}{ DA05 } & 2,5493 & 0,147 & 0,235 & 2,5409 & 2,070 & 1,378 \\
\hline & & 0,349 & & & 1,270 & \\
\hline & & 0,197 & & & 1,110 & \\
\hline & & 0,608 & & & 1,180 & \\
\hline \multirow[t]{4}{*}{ DA06 } & 2,7608 & 0,307 & 0,382 & 2,7500 & 1,360 & 1,270 \\
\hline & & 0,276 & & & 1,180 & \\
\hline & & 0,335 & & & 1,360 & \\
\hline & & 0,480 & & & 0,961 & \\
\hline \multirow[t]{3}{*}{ DA07 } & 2,6859 & 0,337 & 0,377 & 2,6744 & 0,867 & 1,120 \\
\hline & & 0,300 & & & 1,470 & \\
\hline & & 0,390 & & & 1,180 & \\
\hline
\end{tabular}




\begin{tabular}{|c|c|c|c|c|c|c|}
\hline \multirow{5}{*}{ DA08 } & \multirow{4}{*}{2,7135} & 0,223 & \multirow{4}{*}{0,264} & \multirow{4}{*}{2,7049} & 0,984 & \multirow{4}{*}{1,058} \\
\hline & & 0,209 & & & 1,230 & \\
\hline & & 0,375 & & & 0,767 & \\
\hline & & 0,248 & & & 1,250 & \\
\hline & & 0,906 & & & 1,330 & \\
\hline \multirow[t]{4}{*}{ DA09 } & 2,7915 & 0,592 & 0,675 & 2,7760 & 2,320 & 1,610 \\
\hline & & 0,569 & & & 1,690 & \\
\hline & & 0,634 & & & 1,100 & \\
\hline & & 0,591 & & & 1,730 & \\
\hline \multirow[t]{3}{*}{ DA10 } & 2,6500 & 1,010 & 0,606 & 2,6395 & 1,440 & 1,243 \\
\hline & & 0,377 & & & 1,150 & \\
\hline & & 0,446 & & & 0,652 & \\
\hline M & 2,5981 & - & 0,395 & 2,5889 & - & 1,193 \\
\hline
\end{tabular}

M= Média

Dispersalloy com adesivo PAAMA-2 (DP)

\begin{tabular}{|c|c|c|c|c|c|c|}
\hline $\begin{array}{l}\text { Ligal } \\
\text { cdp }\end{array}$ & $\begin{array}{c}\text { idade }=1 \mathrm{~h} \\
\text { peso }(\mathrm{g})\end{array}$ & $\begin{array}{l}\text { rugosidade } \\
\text { inicial }(\mu \mathrm{m})\end{array}$ & $\begin{array}{l}\text { médias } \\
(\mathrm{Ra}=\mu \mathrm{m})\end{array}$ & $\begin{array}{c}\text { idade }=24 \mathrm{~h} \\
\text { peso }(\mathrm{g})\end{array}$ & $\begin{array}{c}\text { rugosidade } \\
\text { final }(\mu \mathrm{m})\end{array}$ & $\begin{array}{c}\text { médias } \\
(\mathrm{Ra}=\mu \mathrm{m})\end{array}$ \\
\hline \multirow{5}{*}{ DP01 } & & 0,343 & & & 1,140 & \\
\hline & 2,7006 & 0,240 & 0,249 & 2,6920 & 0,756 & 0,942 \\
\hline & & 0,241 & & & 1,040 & \\
\hline & & 0,173 & & & 0,833 & \\
\hline & & 0,875 & & & 0,641 & \\
\hline \multirow[t]{4}{*}{ DP02 } & 2,5230 & 0,696 & 0,778 & 2,5137 & 0,840 & 0,869 \\
\hline & & 0,671 & & & 1,030 & \\
\hline & & 0,869 & & & 0,966 & \\
\hline & & 0,430 & & & 2,170 & \\
\hline \multirow[t]{4}{*}{ DP03 } & 2,7000 & 0,414 & 1,461 & 2,6908 & 1,800 & 1,895 \\
\hline & & 3,700 & & & 1,500 & \\
\hline & & 1,300 & & & 2,110 & \\
\hline & & 0,634 & & & 1,730 & \\
\hline \multirow[t]{4}{*}{ DP04 } & 2,7500 & 0,485 & 0,685 & 2,7412 & 2,090 & 1,502 \\
\hline & & 0,401 & & & 1,280 & \\
\hline & & 1,220 & & & 0,909 & \\
\hline & & 0,327 & & & 1,190 & \\
\hline \multirow[t]{4}{*}{ DP05 } & 2,7129 & 0,291 & 0,451 & 2,7045 & 0,715 & 0,975 \\
\hline & & 0,335 & & & 1,060 & \\
\hline & & 0,852 & & & 0,934 & \\
\hline & & 0,574 & & & 1,220 & \\
\hline \multirow[t]{4}{*}{ DP06 } & 2,5500 & 0,655 & 0,528 & 2,5400 & 0,993 & 1,313 \\
\hline & & 0,572 & & & 1,860 & \\
\hline & & 0,312 & & & 1,180 & \\
\hline & & 0,469 & & & 4,440 & \\
\hline DP07 & 2,3639 & 0,797 & 0,686 & 2,3560 & 3,880 & 3,738 \\
\hline
\end{tabular}




\begin{tabular}{|c|c|c|c|c|c|c|}
\hline \multirow{6}{*}{ DP08 } & \multirow{6}{*}{2,3914} & 0,575 & \multirow[b]{4}{*}{0,301} & \multirow[b]{4}{*}{2,3838} & 2,520 & \multirow{5}{*}{1,725} \\
\hline & & 0,903 & & & 4,110 & \\
\hline & & 0,454 & & & 2,270 & \\
\hline & & 0,298 & & & 1,410 & \\
\hline & & 0,242 & & & 1,900 & \\
\hline & & 0,210 & & & 1,320 & \\
\hline \multirow{5}{*}{ DP09 } & & 0,318 & & & 1,340 & \\
\hline & 2,4586 & 0,641 & 0,405 & 2,4505 & 1,310 & 1,275 \\
\hline & & 0,396 & & & 1,180 & \\
\hline & & 0,266 & & & 1,270 & \\
\hline & & 0,901 & & & 3,570 & \\
\hline \multirow[t]{3}{*}{ DP10 } & 2,4930 & 1,020 & 0,654 & 2,4861 & 1,500 & 2,503 \\
\hline & & 0,396 & & & 1,340 & \\
\hline & & 0,300 & & & 3,600 & \\
\hline M & 2,5643 & - & 0,620 & 2,5559 & - & 1,674 \\
\hline
\end{tabular}

$\mathbf{M}=$ Média 


\section{REFERÊNCIAS BIBLIOGRÁFICAS*}

1 ABREU, P.H. Resistência à compressão e à tração diametral de amálgama e liga de gálio, com e sem adesivos. Bauru, 1998. 100p. Dissertação (Mestrado) - Faculdade de Odontologia de Bauru, Universidade de São Paulo.

2 AL DUWAIRI. Y; HADJI-HAMOU, R. Amalgam restorations. A new approach. J. prosth. Dent., v.69, p.138-40, 1993.

3 AMERICAN DENTAL ASSOCIATION. Council on Dental Materials and Devices. Specification $\mathrm{n}^{0} 1$ for alloy for dental amalgam. J. Amer. dent. Ass., v.95, n.3, p.614-7, Sept. 1977.

4 ASGAR, K. Amalgam alloy with a single composition behavior similar to Dispersalloy. J. dent. Res., v.53, p.60, 1974.

5 BARATIERI, L.N. et al. Ligas para amálgama convencionais ou enriquecidas com cobre. Rev. gaúcha Odont., v.32, n.4, p.327-32, out./dez., 1984.

6 BERRY, T.G.; NICHOLSON, J.; TROENDLE, K. Almost two centuries with amalgam: where are we today? J. Amer. dent. Ass., v.125, p.392-9, Apr. 1994.

\footnotetext{
* Normas recomendadas para uso no âmbito da Universidade de São Paulo, com base no documento "Referências Bibliográficas: exemplos", emanado do Conselho Supervisor do Sistema Integrado de Bibliotecas da USP, em reunião de 20 de setembro de 1990.
} 
7 BLACK, G.V. Operative Dentistry. 6. ed. Chicago, Medico-Dental, 1908, p.167-77.

8 BLAIR, F.M.; WHITWORTH, J.M.; McCABE, J.F. The physical properties of a gallium alloy restorative material. Dent. Mat., v.11, n.4, p.277-80, July 1995.

9 BRAGA, R.T. Correntes elétricas na cavidade oral causadas por obturações metálicas. Corrosão das obturações de amálgama produzida por correntes elétricas. An. Fac. Nac. Odont., v.12, p.176-80, 1959.

10 BRÄNNSTRÖM, M.; ASTRÖM, A. The hydrodynamics of the dentine; its possible relationship to dentinal pain. Int. dent. J., v.22, p.219-27, 1972.

11 BUONOCORE, M.G. A simple method of increasing the adhesion of acrylic filling materials to enamel surfaces. J. dent. Res., v.34, n.6, p.849-53, Dec. 1955.

12 BUSATO, A.L.S. et al. Restaurações complexas de amálgama. In:

Restaurações em dentes posteriores. São Paulo, Artes Médicas, 1996. Cap. 9, p.125-96.

13 CHANDLER, J.E.; MESSER, H.H.; ELLENDER, G. Cytotoxicity of gallium and indium ions compared with mercuric ion. J. dent. Res., v.73, n.9, p.154-9, Sept. 1994. 
14 CHANG, J.C. et al. Microleakage of a 4-methacryloxyethyl trimellitate anhydride bonding agent with amalgams. J. prosth. Dent., v.75, n.5, p.495-8, May 1996.

15 CHARBENEAU, G.T. et al. A restauração a amálgama. In:

Dentística operatória. Rio de Janeiro, Guanabara Koogan, 1975. Cap.3, p.248-52.

16 COOLEY, R.L.; TSENG, E.Y.; BARKMEIER, W.W. Dentinal bond strengths and microleakage of a 4-META adhesive to amalgam and composite resin. Quintessence Int., v.22,n.12, p.979-83, Dec.1991.

17 CRAIG, R.G. Amalgam. In: Restorative dental materials. St. Louis, C.V. Mosby, 1985. Cap.5, p.198-223.

18 CRAWFORD, P.R. The story of silver amalgam (and how a canadian changed it all!). J. Canad. dent. Ass., v.55, n.11, p.887-90, Nov. 1989.

19 DENEHY, G.E. The bonded amalgam restoration. Dent. Econ., v.83, n.6, p.104-5, June 1993.

20 DESCHEPPER et al. Corrosion behavior and characterization of a galliumbased alloy. J. dent. Res., v.74, p.103, 1995. Special issue./ Abstract n.736/

21 DEVLIN, H. New developments in tooth restoration with amalgam. Dent. Update, v.20, n.1, p.21-4, Jan./Feb. 1993. 
22 EAKLE, W.S.; STANINEC, M.; LACY, A.M. Effect of bonded amalgam on the fracture resistance of teeth. J. prosth. Dent., v.68, n.2, p.257-60, Aug. 1992.

23 EAKLE, W.S. et al. Mechanical retention versus bonding of amalgam and gallium alloy restorations. J. prosth. Dent., v.72, n.4, p.351-4, Oct. 1994.

24 ENDO, K.; OHNO, H.; OKABE, T. Corrosion behavior of gallium alloy in saline solution. J. dent. Res., v.70, p.486, 1991. Special issue./ Abstract n.1760/ 25 ENGLE, J.H. et al. Quantitation of total mercury vapor released during dental procedures. Dent. Mat., v.8, p.176-80, May 1992.

26 FICHMAN, D.M.; SILVA, J.N.; GUIDI, D. Dispensadores de limalha e mercúrio. Rev. Ass. paul. cirurg. Dent., v.27, n.6, p.339-45, nov./dez. 1973.

27 GALANTE, M. Depoimento exclusivo. Rev. gaúcha Odont., v.27,n.2,p.111-4, abr./jun. 1979.

$28 \mathrm{HABU}, \mathrm{H}$. Study of influences of amalgams trituration upon corrosion.

J. Nihon Univ. Sch. Dent., v.2, n.3, p.127-30, Mar. 1960.

29 HADAVI et al. Repair of high-copper amalgam with and without an adhesive system: In vitro assessment of microleakage and shear bond strength. Gen. Dent., v.41, n.1, p.49-53, Jan./Feb. 1993.

30 HADAVI, F. et al. Bonding amalgam to dentin by different methods. J. prosth. Dent., v.72, n.3, p.250-4, Sept. 1994. 
31 HAGIWARA, Y. et al. Study on mutagenicity of a new gallium alloy for dental restorations. J. J. Dent. Mat., v.15, p.115-6, 1990.

32 HOSOYA, N.; LAUTENSCHLAGER, E.P.; GREENER, E.H. A study of the apical microleakage of a gallium alloy as a retrograde filling material.

J. Endod., v.21, n.9, p.456-8, Sept. 1995.

33 INNES, D.B.K.; YOUDELIS, W.D. Dispersion strengthened amalgams.

J. Canad. dent. Ass., v.29, n.9, p.587-93, Sept. 1963.

34 JORDAN, R.E.; SUZUKI, M.; BALANKO, M. Bonded silver amalgam restorations. J. Canad. dent. Ass., v.58, n.18, p.817-9, Oct. 1992.

35 JORGENSEN, R.B. et al. Characterization of two gallium alloys with and without palladium. J. dent. Res., v.73, p.981, Apr. 1994. / Abstract n.341 /

36 KAGA, M. et al. Gallium alloy restorations in primary teeth: a 12-month study. J. Amer. dent. Ass., v.127, p.1195-200, Aug. 1996.

37 KAWAKAMI, M.; STANINEC,M. Shear bond strength of amalgam adhesives to dentin. J. dent. Res., v.70, p.300, 1991. Special issue. / Abstract n.276 /

38 KNIGHT, G.T.; BERRY, T.G. Clinical application of a direct placement mercuryfree alloy. Am. j. Dent., v.10, n.1, Feb. 1997. 
39 LACY, A.M.; RUPPRECHT, R.; WATANABE, L. Use of self-curing composite resins to facilitate amalgam repair. Quintessence Int., v.23, n.1, p.53-9, Jan. 1992.

40 LACY, A.M.; STANINEC, M.A. The bonded amalgam restoration. Quintessence Int., v.20, n.7, p.521-4, July 1989.

41 LEINFELDER, K.F. After amalgam, what? Other materials fall short. J. Amer. dent. Ass., v.125, p.586-9, May 1994.

42 LIA, I.S. et al. Resistência à corrosão do amálgama submetido a tratamento desoxidante. Rev. Fac. Odont. Bauru, v.2, n.1, p.29-40, jan./fev./março 1994.

43 LYON, H.W.; WATERSTRAT, R.M.; PAFFENBARGER, G.C. Soft tissues response to implants of gallium alloys and silver amalgam alloys. J. Amer. dent. Ass., v.72, n.3, p.659-64, Mar. 1966.

44 MAHLER, D.B. et al. One-year clinical evaluation of bonded amalgam restorations. J. Amer. dent. Ass., v.127, p.345-9, Mar. 1996.

45 MARGRAF, M.T.; GOMES, J.C. Restauração de amálgama adesivo. Rev. gaúcha Odont., v.43, n.6, p.317-20, nov./dez. 1995.

$46 \mathrm{MASH}$ et al. Handling characteristics of gallium alloy for dental restoration.

J. Dent., v.21, n.6, p.350-4, Dec. 1993. 
47 MASUHARA, T.; NAKAMURA, Y.; KUWASHIMA, H. Study on toxicity of a new gallium alloy for dental restorations - subacute oral toxicity test of gallium alloy in rats. Dent. HIth., v.37, p.372-8, 1987.

48 MILLER, B.H. et al. Bond strengths of various materials to dentin using Amalgambond. Am. J. Dent., v.5, n.5, p.272-6, Oct. 1992.

49 MILLER, B.H. et al. Physical and mechanical properties of three gallium alloys. J. dent. Res., v.73, p.129, 1994. / Abstract n.221 /

50 MONDELLI, J. Estudo de algumas propriedades de ligss metálicas, utilizadas na obtenção de incrustações dentais, como possívieis sucedâneas das ligas de ouro. Bauru, 1967. 152p. Tese (Doutorado) Faculdade de Odontologia de Bauru, Universidade de São Paulo.

51 MOMOI, Y. et al. A suggested method for mixing direct filling restorative gallium alloy. Oper. Dent., v.27, n.1, p.12-6, Jan./Feb. 1996.

52 NAGEM FILHO, H. Amálgama. Materiais dentários. FOB-USP, 1989.

53 NAKABAYASHI, N.; WATANABE, A.; GENDUSA, N.J. Dentin adhesion of "modified" 4-META/MMA-TBB resin: function of HEMA. Dent. Mat., v.8, n.4, p.259-64, July 1992.

54 NAKAJIMA, H.; HORASAWA, N.; OKABE, T. Behavior of pure gallium in water and saline solution. J. dent. Res., v.73, p.129, 1994. Special issue./ Abstract n.219/ 
55 NAKAJIMA, H.; WOLDU, M.; OKABE, T. Mechanical properties of gallium alloy and amalgam after saline immersion. J. dent. Res., v.74, p.103, 1995. Special issue/ Abstract n.731/

56 NASCIMENTO, T.N. et al. Fuga de mercúrio ocorrida durante a trituração mecânica da amálgama. Rev. port. Odont., n.15, p.9-14, Jan. 1991.

57 NAVARRO, M.F.L. et al. Clinical evaluation of gallium alloy as a posterior restorative material. Quintessence Int., v.27, n.5, p.315-20, May 1996.

58 NEO, J. et al. Clinical evaluation and microstructural analysis of a direct placement gallium restorative alloy. J. Dent., v.28, n.2, p.123-9, Feb. 2000.

59 OKABE,T; WOLDU, M.K.; NAKAJIMA, H. Characterization of a gallium alloy for dental restoration. J. dent. Res., v.70, p.343, 1991. Special issue.

/ Abstract n.624 /

60 OKABE, T.; WOLDU, M.K.; NAKAJIMA, H. Corrosion behavior of two commercial gallium alloys in $\mathrm{NaCl}$ solution. J. dent. Res., v.74, p.104, 1995. Special Issue./ Abstract n.739/

61 OKAMOTO, Y.; HORIBE, T. Liquid gallium alloys for metallic plastic fillings. Brit. dent. J., v.170, n.1, p.23-6, Jan. 1991.

62 OKAMOTO, Y.; HORIBE, T.; YAMAMOTO, H. Gallium alloy for dental restorations. US patent $n^{\circ} .746,883,1987$. 
63 OSBORNE, J.W. Photoelastic assessment of the expansion of directplacement gallium restorative alloys. Quintessence Int., v.30, n.3, p.18591, March 1999.

64 OSBORNE, J.W.; SUMMITT, J.B. 2-year clinical evaluation of a gallium restorative alloy. Am. J. Dent., v.9, n.5, Oct. 1996.

65 OSBORNE, J.W.; SUMMITT, J.B. Direct-placement gallium restorative alloy: a 3-year clinical evaluation. Quintessence Int., v.30, n.1, p.49-53, Jan. 1999.

66 OSBORNE et al. In vitro wear, tensile strength, and hardness of a gallium alloy. J. dent. Res., v.74, p.103, 1995. Special issue./ Abstract n.734/

67 OSHIDA, Y.; MOORE, B.K. Anodic polarization behavior and microstructure of a gallium-based alloy. Dent. Mat., v.9, n.4, p.234-41, July 1993.

68 PEGORARO, C.N.; MONDELLI, J. Resistência à fratura de dentes restaurados com amálgama adesivo. In: REUNIÃO CIENTÍFICA DA SOCIEDADE BRASILEIRA DE PESQUISA ODONTOLÓGICA, 12. Águas de São Pedro, 1995. Anais. Bauru, SBPqO, 1995. p.66 / Resumo n.132 /

69 PHILLIPS, R.W. Physical properties of amalgam as influenced by the mechanical amalgamator and pneumatic condenser. J. Amer. dent. Ass., v.31, n.18, p.1308-23, Sept. 1944.

70 PHILLIPS, R.W. Compressive strength of amalgam as related to time. J. dent. Res., v.28, n.4, p.348-55, Oct.1949. 
71 PHILLIPS, R.W. Ligas para amálgama dentário: considerações técnicas. In: . Materiais dentários de Skinner. 8. ed. Rio de Janeiro, Interamericana, 1984. Cap.18, p.241-58.

72 PHILLIPS, R.W.; BOYD, D.A. Importance of the mercury-alloy ratio to the amalgam filling. J. Amer. dent. Ass., v.34, n.6, p.451-8, Mar. 1947.

73 PINTO, M.B. Avaliação da infiltração marginal em restaurações com amálgama utilizando como materiais intermediários verniz cavitário e diferentes sistemas adesivos. Bauru, 1997. 209p. Dissertação (Mestrado) - Faculdade de Odontologia de Bauru, Universidade de São Paulo.

74 PLEASURE, M. The corrosion of metals. Dent. Rec., v.48, p.169, 1928.

75 PRAZERES, P.S.L.; BALLESTER, R.Y.; SANTOS, J.F.F. Contribuição para o estudo sobre a viabilidade de uso clínico de uma liga de gálio. RPG, v.3, n.4, p.274, out./dez. 1996

76 PSARRAS, V.; WENNBERG, A.; DÉRAND, T. Cytotoxicity of corroded gallium and dental amalgam alloys. Acta odont. scand., v.50, n.1, p.31-6, 1992.

77 ROCKWELL et al. Cytotoxicity of commercial gallium alloys. J. dent. Res., v.76, p.199, 1997. Special issue./ Abstract n.1485/

78 RUZICKOVA, T. et al. Bonded amalgam restorations: one year clinical results. J. dent. Res., v.75, p.176, 1996. Special issue. / Abstract n.1267 / 79 RUZICKOVA, T. et al. Bonded amalgam restorations: two years clinical results. J. dent. Res., v.76, p.67, 1997. Special issue. / Abstract n.426 / 
80 SAITO, C.; FUSAYAMA, T. Adhesive and sealing properties of gallium alloy. J. dent. Res., v.54, n.4, p.916, July/Aug. 1975.

81 SARKAR et al. Long-term corrosion of a Ga-containing restorative material. Dent. Mat., v.16, n.2, p.97-102, 2000.

82 SETCOS, J.C.; STANINEC, M.; WILSON, N.H.F. Bonding of amalgam restorations: existing knowledge and future prospects. Oper. Dent., v.25, n.2, p.121-9, March-April 2000.

83 SHIMIZU, A.; UI, T.; KAWAKAMI, M. Bond strength between amalgam and tooth hard tissues with application of fluoride, glass ionomer cement and adhesive resin cement in various combinations. Dent. Mat. J., v.5, n.2, p.225-32, 1986.

84 SMITH, D.L.; CAUL, H.J. Alloys of gallium with powdered metals as possible replacement for dental amalgam. J. Amer. dent. Ass., v.53, n.3, p.315-24, Sept. 1956.

85 SMITH, D.L.; CAUL, H.J.; SWEENEY, W.T. Some physical properties of gallium-copper-tin alloys. J. Amer. dent. Ass., v.53, n.6, p.677-85, Dec. 1956.

86 STANINEC, M. Retention of amalgam restorations: undercuts versus bonding. Quintessence Int., v.20, n.5, p.347-51, 1989.

87 STANINEC, M.; HOLT, M. Bonding of amalgam to tooth structure: Tensile adhesion and microleakage tests. J. prosth. Dent., v.59, n.4, p.397-402, Apr. 1988. 
88 SWARTZ, M.L.; PHILLIPS, R.W.; TANNIR, M.S.E. Tarnish of certain dental alloys. J. dent. Res., v.37, n.5, p.837-47, Sept./Oct. 1958.

89 TANGSGOOLWATANA, J. et al. Microleakage evaluation of bonded amalgam restorations: confocal microscopy versus radioisotope. Quintessence Int., v.28, n.7, p.467-77, July 1997.

90 TEMPLE-SMITHSON, P.E.; CAUSTON, B.E.; MARSHALL, K.F. The adhesive amalgam - fact or fiction? Brit. dent. J., v.72, n.8, p.316-9, Apr. 1992.

91 TRUSHKOWSKY, R. Restoration of a cracked tooth with a bonded amalgam. Quintessence Int., v.22, n.5, p.397-400, May 1991.

92 TUCCILLO, J.J.; NIELSEN, J.P. Observation of onsert of sulfide tarnish on gold-base alloys. J. prosth. Dent., v.25, n.6, p.629-37, June 1971.

93 VARGA, J.; MATSUMURA, H.; MASUHARA, E. Bonding of amalgam filling to tooth cavity with adhesive resin. Dent. Mat. J., v.5, n.2, p.158-64, 1986.

94 VENUGOPALAN, R.; BROOME, J.C.; LUCAS, L.C. Dimensional change and corrosion evaluation of Galloy. J.dent. Res., v.76, p.198, 1997. Special issue./ Abstract n.1479/

95 VIEIRA, D.F. Metais e ligas metálicas: noções básicas para os dentistas. 2.ed. rev. at. São Paulo, Ed. Edgard Blucher, 1967. p.143-57.

96 VILLELA, L.C.; GALAN JR., J.; MONDELLI, J. Influência da técnica de condensação em algumas propriedades físicas de amálgamas preparados 
com diferentes tipos de partículas. Ars curandi Odont., v.6, n.3, p.53-60, jun. 1979.

97 WATAHA et al. Correlation of cytotoxicity with elemental release from mercuryand gallium-based dental alloys in vitro. Dent. Mat., v.10, n.5, p.298-303, Sept. 1994.

98 WATERSTRAT, R.M. Evaluation of a gallium-palladium-tin alloy for restorative dentistry. J. Amer. dent. Ass., v.78, n.3, p.536-41, Mar. 1969.

100 WILLIANS, R.V. Use of indium in dental alloys. J. Amer. Coll. Dent., v.5, p.78, 1938.

101 YAMASHITA, T.; ITOH, K.; WAKUMOTO, S. Clinical study of an experimental gallium-containing alloy. Dent. Mater. J., v.8, p.135-40, 1989. 


\section{ABSTRACT}

The resistance to the corrosion was evaluated through weight loss to an alternated immersion (solution-air) and its consequent changes on the surface of three restoring materials (them amalgams Dispersalloy and Tytin Plus, both with high copper content, respectively dispersion phase and unique particle, as well as the alloy gallium base Galloy), associated or not to two adhesive systems (All-Bond 2 and PAAMA-2), observed by measuring the surface roughness. Ten bodies-oftest were made, for each specific condition, in a metallic matrix os stainlesss steel with five cilindrical cavities, measuring $10,7 \mathrm{~mm}$ in diameter and 3,0 $\mathrm{mm}$ thickness each one. After polishing, as in the metalographic anal ysis, the specimens were weighed and submitted to the roughness measurer to measuring inicial. These were submitted to an alternated immersion in $5 \%$ sodium sulfide solution, for 24 hours and then the second weighting was performed and obtained the average values of weight loss. A second measure of the surface roughness was then performed. The results were registered and submitted to the variance analysis, to two approaches, and to the test of contrasts of Tukey-Kramer. From the obtained results, it was concluded that all specimens lost weight and there was an increasing roughness surface after immersion in corrosive solution; Galloy showed higher values, both weight loss test and the rougness surface, compared to two amalgams; the alloy Tytin Plus obtained better results; there was significant statistical difference among the restoring materials, but not among adhesive systems, showing different behaviors according to arrangement of these factors. 